\title{
Two Pathways for Electrocatalytic Oxidation of Hydrogen by a Nickel Bis(diphosphine) Complex with Pendant Amines in the Second Coordination Sphere
}

\author{
Jenny Y. Yang, ${ }^{*},{ }^{\dagger}$ Stuart E. Smith, ${ }^{\dagger}$ Tianbiao Liu, ${ }^{\dagger}$ William G. Dougherty, ${ }^{\ddagger}$ Wesley A. Hoffert, ${ }^{\dagger}$
}

W. Scott Kassel, ${ }^{\dagger}$ M. Rakowski DuBois, ${ }^{\dagger}$ Daniel L. DuBois, ${ }^{\dagger}$ and R. Morris Bullock ${ }^{*}{ }^{\dagger}$

${ }^{\dagger}$ Center for Molecular Electrocatalysis, Pacific Northwest National Laboratory, P.O. Box 999, K2-57, Richland, Washington 99352, United States

${ }^{\ddagger}$ Department of Chemistry, Villanova University, Villanova, Pennsylvania 19085, United States

Supporting Information

ABSTRACT: A nickel bis(diphosphine) complex containing pendant amines in the second coordination sphere, $[\mathrm{Ni}-$ $\left.\left(\mathrm{P}_{2}^{\mathrm{Cy}} \mathrm{N}^{t-\mathrm{Bu}}{ }_{2}\right)_{2}\right]\left(\mathrm{BF}_{4}\right)_{2}\left(\mathrm{P}^{\mathrm{Cy}}{ }_{2} \mathrm{~N}^{t-\mathrm{Bu}}{ }_{2}=1,5\right.$-di(tert-butyl)-3,7-dicyclohexyl-1,5-diaza-3,7-diphosphacyclooctane), is an electrocatalyst for hydrogen oxidation. The addition of hydrogen to the $\mathrm{Ni}^{\mathrm{II}}$ complex gives three isomers of the doubly protonated $\mathrm{Ni}^{0}$ complex $\left[\mathrm{Ni}\left(\mathrm{P}^{\mathrm{Cy}}{ }_{2} \mathrm{~N}^{t-\mathrm{Bu}}{ }_{2} \mathrm{H}\right)_{2}\right]\left(\mathrm{BF}_{4}\right)_{2}$. Using the $\mathrm{p} K_{\mathrm{a}}$ values and $\mathrm{Ni}^{\mathrm{II} / \mathrm{I}}$ and $\mathrm{Ni}^{\mathrm{i} / 0}$ redox potentials in a thermochemical cycle, the free energy of hydrogen addition to $\left[\mathrm{Ni}\left(\mathrm{P}^{\mathrm{Cy}}{ }_{2} \mathrm{~N}^{t-\mathrm{Bu}}{ }_{2}\right)_{2}\right]^{2+}$ was determined to be $-7.9 \mathrm{kcal} \mathrm{mol}^{-1}$. The catalytic rate observed in dry acetonitrile for the oxidation of $\mathrm{H}_{2}$ depends on base size, with larger bases $\left(\mathrm{NEt}_{3}, t-\mathrm{BuNH}_{2}\right)$ resulting in much slower catalysis than $n-\mathrm{BuNH}_{2}$. The addition of water accelerates the rate of catalysis by facilitating deprotonation of the hydrogen addition product before oxidation, especially for the larger bases $\mathrm{NEt}_{3}$ and $t-\mathrm{BuNH}_{2}$. This catalytic pathway, where deprotonation occurs prior to oxidation, leads to an overpotential that is $0.38 \mathrm{~V}$ lower compared to the pathway where oxidation precedes proton movement. Under the optimal conditions of $1.0 \mathrm{~atm} \mathrm{H}_{2}$ using $n-\mathrm{BuNH}_{2}$ as a base and with added water, a turnover frequency of $58 \mathrm{~s}^{-1}$ is observed at $23{ }^{\circ} \mathrm{C}$.

\section{INTRODUCTION}

The widespread use of renewable energy will require improved methods of energy storage because of the intermittent nature of energy production from solar and wind power. ${ }^{1}$ Chemical fuels such as hydrogen are ideal because of their high energy density by weight, but electrocatalysts are necessary for both hydrogen production by proton reduction and subsequent oxidation of hydrogen in a fuel cell. Currently, the most efficient and fastest catalyst for hydrogen oxidation is platinum, but its high cost and low abundance limit its general use. ${ }^{2-5}$ The utility of hydrogen as a chemical fuel and as a reductant to generate other chemical fuels has generated a great deal of research interest in catalyst discovery for hydrogen production. Many molecular catalysts for hydrogen production have been discovered using abundant, inexpensive metals such as nickel, ${ }^{6-16}$ cobalt, ${ }^{17-25,59}$ iron, $^{26-33}$ and molybdenum. ${ }^{34,35}$ In contrast, there have been few reported homogeneous catalysts for the reverse reaction, oxidation of hydrogen, which is necessary for efficient fuel utilization. ${ }^{36-52}$

Hydrogenase enzymes catalyze both the production and oxidation of hydrogen at high rates and efficiency using active sites composed of the abundant metals iron and nickel. ${ }^{53,54}$ The $[\mathrm{FeFe}]$ hydrogenase enzyme incorporates a pendant amine in

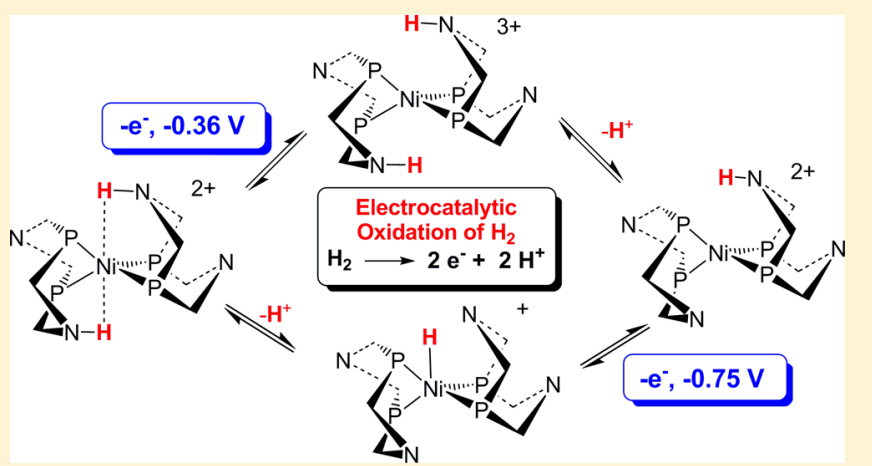

the active site that is believed to be properly positioned to facilitate formation and cleavage of the $\mathrm{H}-\mathrm{H}$ bond. We have reported a series of catalysts based on a nickel bis(diphosphine) framework $\left[\mathrm{Ni}\left(\mathrm{P}_{2}{ }_{2} \mathrm{~N}^{\mathrm{R} \prime}{ }_{2}\right)_{2}\right]^{2+}$, where $\mathrm{P}_{2}{ }_{2} \mathrm{~N}^{\mathrm{R} \prime}{ }_{2}$ is an eightmembered diphosphine ligand with two pendant amines, and $\mathrm{R}$ and $\mathrm{R}^{\prime}$ denote the substituents on the phosphorus and nitrogen, respectively. ${ }^{55-58}$ The noncoordinating tertiary amines are positioned to stabilize binding of $\mathrm{H}_{2}$, serve as a proton acceptor to facilitate the heterolytic cleavage of $\mathrm{H}_{2}$, and mediate proton-coupled electron transfer steps in the catalytic cycle. The complex $\left[\mathrm{Ni}\left(\mathrm{P}^{\mathrm{Cy}}{ }_{2} \mathrm{~N}^{t-\mathrm{Bu}}{ }_{2}\right)_{2}\right]\left(\mathrm{BF}_{4}\right)_{2}$ was recently reported to electrocatalytically oxidize hydrogen with a high turnover frequency (TOF). ${ }^{50}$

In this work we report detailed studies of this catalyst that reveal two separate catalytic pathways that differ by $0.38 \mathrm{~V}$ in overpotential. This difference can be traced to the sequence of proton movement and electron transfer in the catalytic cycle. In addition, we now report the effect of water in accelerating the catalytic rate for hydrogen oxidation, and we attribute this acceleration as kinetically favoring the pathway in which

Received: January 29, 2013

Published: April 30, 2013 


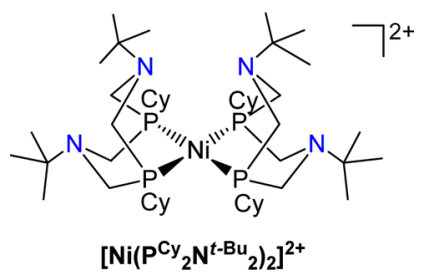

deprotonation occurs prior to oxidation. Thus, the addition of water results in both a reduction in overpotential and a higher catalytic rate. Also, the free energy of heterolytic cleavage of $\mathrm{H}_{2}$ by $\left[\mathrm{Ni}\left(\mathrm{P}^{\mathrm{Cy}}{ }_{2} \mathrm{~N}^{t-\mathrm{Bu}}\right)_{2}\right]\left(\mathrm{BF}_{4}\right)_{2}$ has been calculated from the experimentally determined hydride and proton acceptor energies, as well as electrochemical data. From this thermochemical data and previously reported data, we have determined the effect of varying the functional groups of the ligand on the thermodynamic properties of the nickel complex, and the relationship between driving force for hydrogen addition and catalytic rate. These detailed studies provide mechanistic insights into the role of managing thermodynamic properties and proton movement in significantly reducing the overpotential while increasing the rate in hydrogen oxidation electrocatalysis

\section{RESULTS}

Synthesis and Characterization of $\mathrm{Ni}^{0}\left(\mathrm{P}^{\mathrm{Cy}}{ }_{2} \mathrm{~N}^{t-B u}{ }_{2}\right)_{2}$ and $\left[\mathrm{Ni}^{\prime}\left(\mathrm{P}^{\mathrm{Cy}}{ }_{2} \mathrm{~N}^{t-\mathrm{Bu}}{ }_{2}\right)_{2}\right]\left(\mathrm{BF}_{4}\right)$. The $\mathrm{Ni}^{0}$ complex $\mathrm{Ni}\left(\mathrm{P}^{\mathrm{Cy}}{ }_{2} \mathrm{~N}^{t-\mathrm{Bu}}{ }_{2}\right)_{2}$ was prepared by reaction of $\mathrm{Ni}(\mathrm{COD})_{2}(\mathrm{COD}=1,5$-cyclooctadiene) with 2 equiv of the ligand $\mathrm{P}^{\mathrm{Cy}}{ }_{2} \mathrm{~N}^{\mathrm{t}-\mathrm{Bu}}{ }_{2}(1,5$-di-(tertbutyl)-3,7-dicyclohexyl-1,5-diaza-3,7-diphosphacyclooctane $)^{50}$ under nitrogen at $-40{ }^{\circ} \mathrm{C}$ in tetrahydrofuran. The yellow airsensitive powder was isolated and characterized by ${ }^{31} \mathrm{P}$ and ${ }^{1} \mathrm{H}$ NMR spectroscopy. The ${ }^{31} \mathrm{P}\left\{{ }^{1} \mathrm{H}\right\}$ NMR spectrum in $\mathrm{C}_{6} \mathrm{D}_{6}$ exhibits a singlet at $7.41 \mathrm{ppm}$, typical of tetrahedral (diphosphine) ${ }_{2} \mathrm{Ni}^{0}$ complexes. ${ }^{12,18,60}$

Crystals of $\mathrm{Ni}\left(\mathrm{P}^{\mathrm{Cy}}{ }_{2} \mathrm{~N}^{t-\mathrm{Bu}}{ }_{2}\right)_{2}$ were grown by evaporation of a pentane solution, and the structure was confirmed by a single crystal X-ray diffraction study. The structure is shown in Figure 1 , and selected bond distances and angles are shown in Table 1. The complex has a distorted tetrahedral geometry with all four $\mathrm{Ni}-\mathrm{P}$ bond distances nearly equal at $2.13-2.14 \AA$. The $\mathrm{P}-\mathrm{Ni}-$ $\mathrm{P}$ bond angles for the diphosphine ligand are about $84^{\circ}$, which is significantly smaller than the $109^{\circ}$ expected for an ideal tetrahedron. The smaller bite angle observed for the $\mathrm{P}^{\mathrm{Cy}}{ }_{2} \mathrm{~N}^{t-\mathrm{Bu}}{ }_{2}$

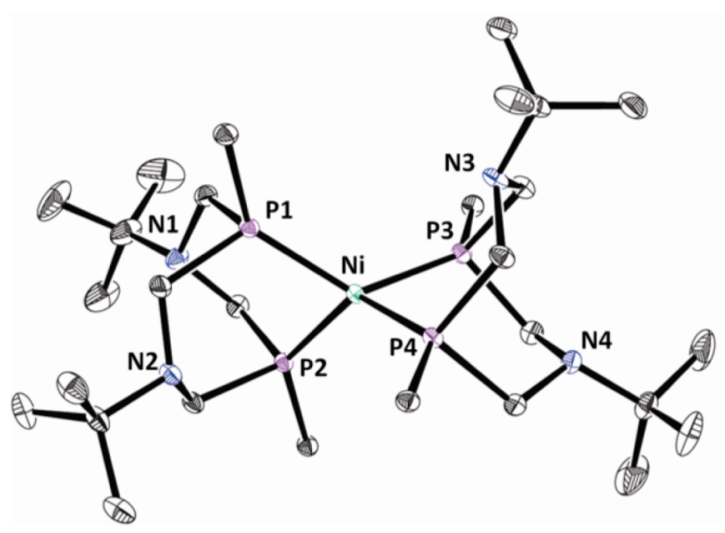

Figure 1. The structure of $\mathrm{Ni}\left(\mathrm{P}^{\mathrm{Cy}}{ }_{2} \mathrm{~N}^{t-\mathrm{Bu}}{ }_{2}\right)_{2}$. Thermal ellipsoids are shown at the $80 \%$ probability level. For clarity, only the carbons of the cyclohexyl rings directly bound to the phosphorus atoms are shown.
Table 1. Selected Bond Distances $(\AA)$ and Angles $\left(^{\circ}\right)$ for $\mathrm{Ni}\left(\mathrm{P}^{\mathrm{Cy}}{ }_{2} \mathrm{~N}^{t-\mathrm{Bu}}{ }_{2}\right)_{2}$ and $\left[\mathrm{Ni}\left(\mathrm{P}^{\mathrm{C} y}{ }_{2} \mathrm{~N}^{t-\mathrm{Bu}}{ }_{2} \mathrm{H}\right)\right]\left(\mathrm{BF}_{4}\right)_{2}$, Isomer $\mathrm{B}$

\begin{tabular}{lll} 
& $\mathrm{Ni}\left(\mathrm{P}_{2}^{\mathrm{Cy}} \mathrm{N}^{\mathrm{t}-\mathrm{Bu}}{ }_{2}\right)_{2}$ & \multicolumn{1}{c}{ isomer $\mathbf{B}$} \\
$\mathrm{Ni}-\mathrm{P} 1$ & $2.1417(4)$ & $2.1394(10)$ \\
$\mathrm{Ni}-\mathrm{P} 3$ & $2.1436(4)$ & $2.1418(9)$ \\
$\mathrm{Ni} \cdots \mathrm{N} 1$ & 3.399 & 3.870 \\
$\mathrm{Ni} \cdots \mathrm{N} 2$ & 3.834 & 3.821 \\
$\mathrm{Ni} \cdots \mathrm{N} 3$ & 3.483 & 3.307 \\
$\mathrm{Ni} \cdots \mathrm{N} 4$ & 3.830 & 3.828 \\
$\mathrm{P} 1-\mathrm{Ni}-\mathrm{P} 2$ & $83.897(15)$ & $85.08(4)$ \\
$\mathrm{P} 3-\mathrm{Ni}-\mathrm{P} 4$ & $85.75(3)$ & $85.75(3)$ \\
\hline
\end{tabular}

ligand is attributed to constraints imposed by the two sixmembered chelate rings in the backbone of the cyclic ligand. Two of the six-membered rings have boat conformations, directing the pendant base toward the metal center $(\mathrm{Ni} \cdots \mathrm{N}$ distances are 3.399 and $3.483 \AA$ ), and the other two are in a chair form (both $\mathrm{Ni} \cdots \mathrm{N}$ distances are $3.83 \AA$ ). The dihedral angle between the two planes formed by the two phosphorus atoms of each diphosphine ligand and the $\mathrm{Ni}$ atom is $84.66^{\circ}$, close to the $90^{\circ}$ angle expected for a tetrahedral complex. We previously reported an alternate preparation by reduction of the corresponding $\mathrm{Ni}^{\mathrm{iI}}$ complex with hydrogen in the presence of a base; $^{50}$ the yield and purity of the complexes prepared by the two methods are comparable.

The $\mathrm{Ni}^{\mathrm{I}}$ complex $\left[\mathrm{Ni}\left(\mathrm{P}^{\mathrm{Cy}}{ }_{2} \mathrm{~N}^{t-\mathrm{Bu}}\right)_{2}\right]\left(\mathrm{BF}_{4}\right)$ was synthesized by reaction of the corresponding $\mathrm{Ni}^{\mathrm{II}}$ and $\mathrm{Ni}^{0}$ complexes. ${ }^{50}$ The $E_{1 / 2}$ of the $\mathrm{Ni}^{\mathrm{iI} / \mathrm{I}}$ and $\mathrm{Ni}^{\mathrm{I} / 0}$ couples for the complex are separated by $0.65 \mathrm{~V}$. This large potential difference leads to clean and quantitative comproportionation of the $\mathrm{Ni}^{\mathrm{II}}$ and $\mathrm{Ni}^{0}$ complexes to generate the orange air-sensitive $\mathrm{Ni}^{\mathrm{I}}$ complex. The magnetic moment was measured using the Evans method. ${ }^{61-63}$ In an acetonitrile solution, $\mu_{\text {eff }}$ for $\left[\mathrm{Ni}^{\mathrm{I}}\left(\mathrm{P}^{\mathrm{Cy}}{ }_{2} \mathrm{~N}^{t-\mathrm{Bu}}{ }_{2}\right)_{2}\right]\left(\mathrm{BF}_{4}\right)$ is $1.90 \mu_{\mathrm{B}}$ at $293 \mathrm{~K}$. This value is close to the expected spin-only value for a $S=1 / 2 \mathrm{Ni}^{\mathrm{I}}$ center, assuming $g=2.0\left(0.375 \mathrm{emu} \cdot \mathrm{K} \cdot \mathrm{mol}^{-1}\right)$. However, late transition metal ions like $\mathrm{Ni}^{n+}$ often exhibit $g$-values slightly larger than 2.0 because of spin-orbit coupling, so the measured susceptibility value is consistent with a $S=1 / 2 \mathrm{Ni}^{\mathrm{I}}$ ion. The cyclic voltammogram of the complex in acetonitrile displays two reversible one-electron couples that match the half-wave potentials for the $\mathrm{Ni}^{\mathrm{iI} / \mathrm{I}}$ and $\mathrm{Ni}^{\mathrm{I} / 0}$ couples for the corresponding $\mathrm{Ni}^{\mathrm{II}}$ complex (at -0.77 and $-1.42 \mathrm{~V}$, respectively, versus the $\mathrm{Cp}_{2} \mathrm{Fe}^{+/ 0}$ couple).

Products of the Addition of Hydrogen to [Ni$\left.\left(\mathrm{P}^{\mathrm{Cy}}{ }_{2} \mathrm{~N}^{t-\mathrm{Bu}}{ }_{2}\right)_{2}\right]\left(\mathrm{BF}_{4}\right)_{2}$. Addition of dry hydrogen to a solution of $\left[\mathrm{Ni}\left(\mathrm{P}^{\mathrm{Cy}}{ }_{2} \mathrm{~N}^{t-\mathrm{Bu}}\right)_{2}\right]^{2+}$ in anhydrous $\mathrm{CD}_{3} \mathrm{CN}$ leads to a rapid reaction at room temperature, forming the doubly protonated $\mathrm{Ni}^{0}$ complex $\left[\mathrm{Ni}\left(\mathrm{P}^{\mathrm{Cy}}{ }_{2} \mathrm{~N}^{t-\mathrm{Bu}}{ }_{2} \mathrm{H}\right)_{2}\right]\left(\mathrm{BF}_{4}\right)_{2}$. The reaction goes to completion as observed by ${ }^{31} \mathrm{P}\left\{{ }^{1} \mathrm{H}\right\}$ NMR spectroscopy. Protonation of the pendant amines can occur endo or exo to the metal, as shown in Scheme 1, leading to three isomers. Previous studies on the three closely related isomers of $\left[\mathrm{Ni}\left(\mathrm{P}^{\mathrm{Cy}}{ }_{2} \mathrm{~N}_{2}{ }_{2} \mathrm{H}\right)_{2}\right]^{2+}$ (with benzyl (Bn) on nitrogen) have established their structures by ${ }^{1} \mathrm{H},{ }^{31} \mathrm{P}$, and ${ }^{2} \mathrm{H}$ NMR spectroscopy. ${ }^{7,64}$

The first isomer formed after heterolytic cleavage of hydrogen by $\left[\mathrm{Ni}\left(\mathrm{P}^{\mathrm{Cy}}{ }_{2} \mathrm{~N}^{t-\mathrm{Bu}}{ }_{2}\right)_{2}\right]^{2+}$ is the endo-endo isomer, $\mathbf{A}$, which is observed in the ${ }^{31} \mathrm{P}\left\{{ }^{1} \mathrm{H}\right\}$ NMR spectrum at $14.7 \mathrm{ppm}$ as the sole product. The broad singlet resonance is consistent with a tetrahedral $\mathrm{Ni}^{0}$ complex with a protonated amine in each cyclic ligand. Isomer $\mathbf{B}$ is observed in the ${ }^{31} \mathrm{P}\left\{{ }^{1} \mathrm{H}\right\} \mathrm{NMR}$ 


\section{Scheme 1}
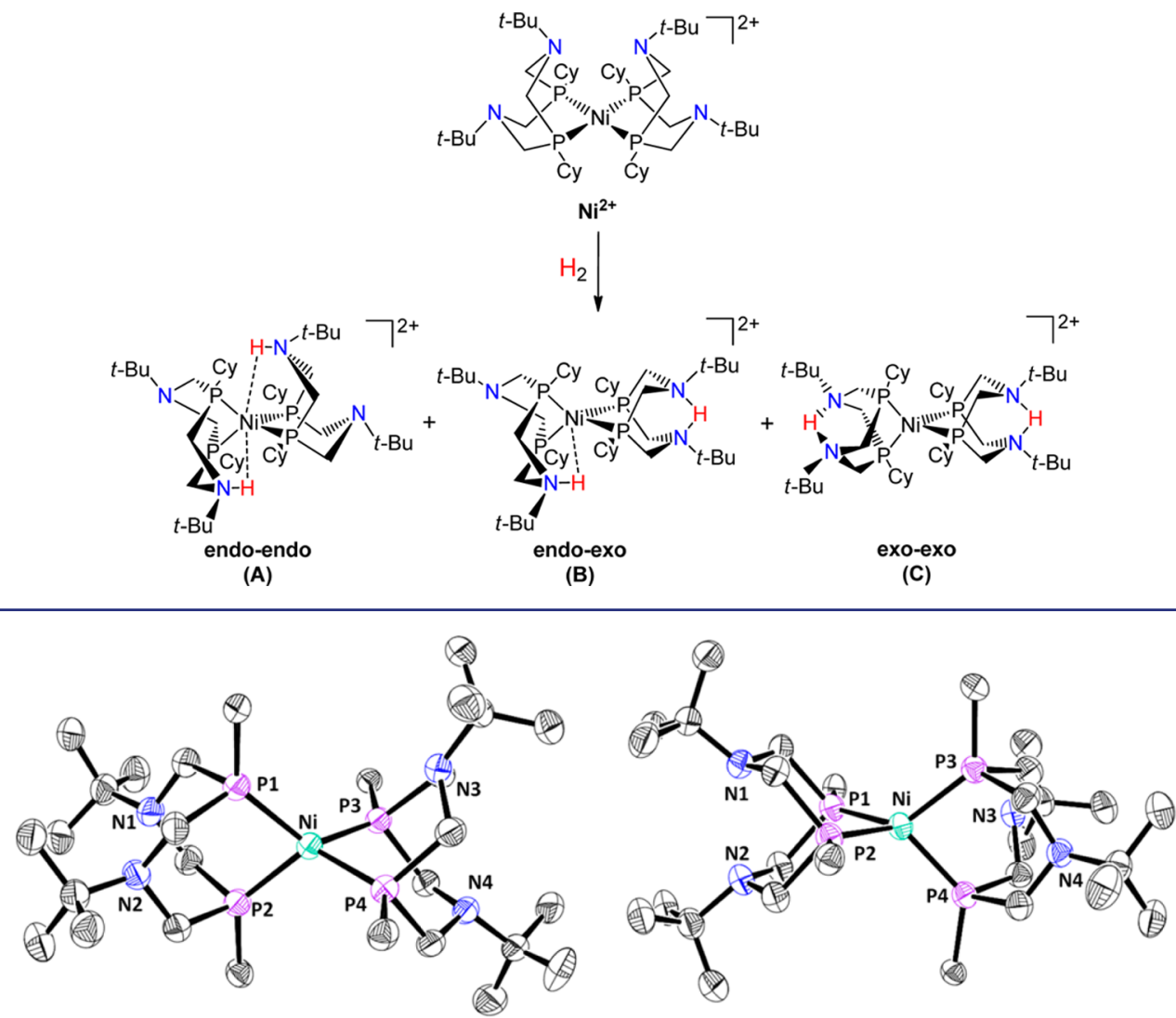

Figure 2. Two views of the structure of the cation of $\left[\mathrm{Ni}\left(\mathrm{P}^{\mathrm{Cy}}{ }_{2} \mathrm{~N}^{\mathrm{t}-\mathrm{Bu}}{ }_{2} \mathrm{H}\right)_{2}\right]\left(\mathrm{BF}_{4}\right)_{2}$, isomer $\mathbf{B}$. Thermal ellipsoids are shown at the $50 \%$ probability level. For clarity, only the carbons of the cyclohexyl rings directly bound to the phosphorus atoms are shown. Hydrogens are not shown.

spectrum after an hour and continues to increase over several hours. Isomer B exhibits two broad singlets of equal intensity at 13.3 and $-11.9 \mathrm{ppm}$ in the ${ }^{31} \mathrm{P}\left\{{ }^{1} \mathrm{H}\right\}$ NMR spectrum. The two resonances are consistent with two inequivalent ligands, and are expected because of the different protonation sites of each ligand. One ligand is protonated on the side of the amine toward the metal (endo), and the other ligand is protonated on the opposite side (exo), forming a $\mathrm{N}-\mathrm{H}-\mathrm{N}$ "pinched" hydrogen bond between the two amines on the same ligand. In a tetrahedral coordination, the two phosphorus atoms on the ligand protonated exo would be expected to show inequivalence due to the endo protonation of the other ligand. However, we have observed rapid intramolecular proton transfer at room temperature of the endo proton to the other nitrogen on the same ligand. ${ }^{64}$ This leads to the single broad resonance observed for the exoprotonated ligand at room temperature. The population of isomer $\mathbf{B}$ increases relative to isomer $\mathrm{A}$ over the next few hours, becoming about $60 \%$ after 6 h. Over the $13 \mathrm{~h}$ that the solution was monitored, isomer $\mathbf{C}$ slowly appeared in the ${ }^{31} \mathrm{P}\left\{{ }^{1} \mathrm{H}\right\}$ NMR spectrum as a singlet at $-10.53 \mathrm{ppm}$. A singlet is consistent with a tetrahedral complex that is protonated in an exo position on both diphosphine ligands, as each phosphorus atom is equivalent. The concentration of isomer $\mathbf{C}$ by integration of the ${ }^{31} \mathrm{P}\left\{{ }^{1} \mathrm{H}\right\}$ NMR spectrum is small ( $4 \%$ after $13 \mathrm{~h}$ ) but increases over time. After $13 \mathrm{~h}$, the concentration of isomer $\mathbf{C}$ was still increasing, while the concentration of isomer $\mathbf{A}$ and $\mathbf{B}$ were still declining. These three isomers are similar to those observed previously for the analogous nickel complex with benzyl substituents on the nitrogen, which display similar resonances in the ${ }^{31} \mathrm{P}\left\{{ }^{1} \mathrm{H}\right\}$ NMR spectrum. $^{64}$

When the same experiment is performed in the presence of 10 equiv of water with respect to $\left[\mathrm{Ni}\left(\mathrm{P}^{\mathrm{Cy}}{ }_{2} \mathrm{~N}^{t-\mathrm{Bu}}{ }_{2}\right)_{2}\right]^{2+}$, an equilibrium distribution of isomers $\mathbf{A}, \mathbf{B}$, and $\mathbf{C}$ is attained much more rapidly. Isomer $\mathbf{B}$ is observed within the first few minutes of hydrogen addition. The amount of isomer A, initially the predominant isomer, rapidly decreases in concentration concomitant with an increase in isomer $\mathbf{C}$. The solution reaches equilibrium after about $5 \mathrm{~h}$. The equilibrium concentration of the isomers was determined by integration of the ${ }^{31} \mathrm{P}\left\{{ }^{1} \mathrm{H}\right\}$ NMR spectrum, and is $8 \% \mathrm{~A}, 16 \% \mathrm{~B}$, and $73 \% \mathrm{C}$.

The addition of hydrogen to $\left[\mathrm{Ni}\left(\mathrm{P}^{\mathrm{Cy}}{ }_{2} \mathrm{~N}^{t-\mathrm{Bu}}{ }_{2}\right)_{2}\right]^{2+}$ at low temperature was examined by ${ }^{31} \mathrm{P}$ NMR spectroscopy to investigate the possibility of observable intermediates (e.g., a $\mathrm{Ni}^{\mathrm{II}}$ dihydrogen complex ${ }^{65,66}$ before the formation of isomer A. Hydrogen was bubbled through a solution of $[\mathrm{Ni}-$ $\left.\left(\mathrm{P}_{2}^{\mathrm{Cy}} \mathrm{N}^{t-\mathrm{Bu}}{ }_{2}\right)_{2}\right]^{2+}$ in $n$-butyronitrile cooled to $-112{ }^{\circ} \mathrm{C}$. The sample was then inserted into an NMR probe precooled to $-100{ }^{\circ} \mathrm{C}$, and a ${ }^{31} \mathrm{P}\left\{{ }^{1} \mathrm{H}\right\} \mathrm{NMR}$ spectrum was collected. The only resonances observed corresponded to $\left[\mathrm{Ni}\left(\mathrm{P}^{\mathrm{Cy}}{ }_{2} \mathrm{~N}^{t-\mathrm{Bu}}{ }_{2}\right)_{2}\right]^{2+}$ and isomer $\mathbf{A}$. As the temperature was warmed to room temperature, the ${ }^{31} \mathrm{P}\left\{{ }^{1} \mathrm{H}\right\}$ NMR spectrum showed complete conversion of $\left[\mathrm{Ni}\left(\mathrm{P}^{\mathrm{Cy}}{ }_{2} \mathrm{~N}^{t-\mathrm{Bu}}{ }_{2}\right)_{2}\right]^{2+}$ to isomer $\mathbf{A}$, thus giving no experimental evidence for intermediacy of the dihydrogen complex $\left[\mathrm{Ni}\left(\mathrm{H}_{2}\right)\left(\mathrm{P}^{\mathrm{Cy}}{ }_{2} \mathrm{~N}^{t-\mathrm{Bu}}{ }_{2}\right)_{2}\right]^{2+}$.

Crystals of isomer $\mathbf{B}$ were grown from diffusion of diethyl ether into an acetonitrile solution of $\left[\mathrm{Ni}\left(\mathrm{P}_{2}^{\mathrm{Cy}} \mathrm{N}^{t-\mathrm{Bu}}{ }_{2}\right)_{2}\right]^{2+}$ that had been purged with hydrogen and cooled to $-45{ }^{\circ} \mathrm{C}$. The 
structure of isomer $\mathbf{B}$ is shown in Figure 2. Although the protons were not located, the orientations of the six-membered rings formed by the ligand and metal support the structure suggested by ${ }^{31} \mathrm{P}\left\{{ }^{1} \mathrm{H}\right\}$ NMR spectroscopy and shown in Scheme 1, and selected bond distances and angles are given in Table 1. The complex has a distorted tetrahedral geometry with all four $\mathrm{Ni}-\mathrm{P}$ bond distances nearly equal at $2.14-2.15 \AA$, similar to the previously examined $\mathrm{Ni}^{0}$ complexes in our laboratory, which have bond distances ranging from 2.11 to $2.15 \AA .^{18,48,60}$ The $\mathrm{P}-\mathrm{Ni}-\mathrm{P}$ bond angles for the two diphosphine ligands are $85.75^{\circ}$ and $85.01^{\circ}$, slightly larger than those observed for $\mathrm{Ni}\left(\mathrm{P}^{\mathrm{Cy}}{ }_{2} \mathrm{~N}^{t-\mathrm{Bu}}{ }_{2}\right)_{2}$. The ligand that is protonated in the "pinched" exo position has both rings in the chair conformation. With the two lone pairs directed toward each other, the distance between the two nitrogens is $2.69 \AA$, consistent with a $\mathrm{N}-\mathrm{H}-\mathrm{N}$ hydrogen bond. These observations are only expected with a proton interacting with both $\mathrm{N}$ atoms of the "pinched" ligand. The $\mathrm{P}^{\mathrm{Cy}}{ }_{2} \mathrm{~N}^{t-\mathrm{Bu}}{ }_{2}$ ligand protonated in the endo position has one six-membered ring in the chair conformation and the other six-membered ring in the boat conformation. The distance between the protonated nitrogen and the metal is $3.31 \AA$, significantly shorter than the $\mathrm{Ni} \cdots \mathrm{N}$ distances of 3.40 and $3.48 \AA$ observed for $\mathrm{Ni}\left(\mathrm{P}^{\mathrm{Cy}}{ }_{2} \mathrm{~N}^{t-\mathrm{Bu}}{ }_{2}\right)_{2}$. This is again consistent with a hydrogen bond between the proton on $\mathrm{N} 3$ and the $\mathrm{Ni}^{0}$.

When crystals were grown using the same solvents, but at room temperature, isomer $\mathbf{C}$ was obtained. The crystals cracked under the cold stream during single crystal X-ray analysis, but a structure was obtained from the data collected. All four of the six-membered rings on the ligand are in chair conformations, which led to our assignment of this structure as isomer $\mathbf{C}$. The structure is reported in the Supporting Information. The complex also adopts a distorted tetrahedral structure with all four $\mathrm{Ni}-\mathrm{P}$ bond distances at $2.13 \AA$. It is interesting that protonation of the ligands on isomers $\mathbf{B}$ and $\mathbf{C}$ do not result in a significant shortening of the $\mathrm{Ni}-\mathrm{P}$ bond compared to the $\mathrm{Ni}^{0}$ complex $\mathrm{Ni}\left(\mathrm{P}^{\mathrm{Cy}}{ }_{2} \mathrm{~N}^{\mathrm{t}-\mathrm{Bu}}{ }_{2}\right)_{2}$, since as a result of the protonation, the ligand becomes cationic. The $\mathrm{P}-\mathrm{Ni}-\mathrm{P}$ bond angles for the diphosphine ligands are $86.07^{\circ}$, again slightly larger than those observed for $\mathrm{Ni}\left(\mathrm{P}^{\mathrm{Cy}}{ }_{2} \mathrm{~N}^{t-\mathrm{Bu}}{ }_{2}\right)_{2}$. The protonated ligands adopt "pinched" exo positions with an average distance between the two disordered nitrogen atoms of $2.63 \AA$, consistent with $\mathrm{NH} \cdots \mathrm{N}$ hydrogen bonds.

Protonation of $\mathrm{Ni}\left(\mathrm{P}^{\mathrm{Cy}}{ }_{2} \mathrm{~N}^{t-\mathrm{Bu}}{ }_{2}\right)_{2}$. Buffered solutions consisting of a mixture of the base 7-methyl-1,5,7-triazabicyclo[4.4.0]dec-5-ene (MTBD) and its protonated form, $[\mathrm{H}$ $\mathrm{MTBD}]^{+} \mathrm{BPh}_{4}^{-}$, were added to $\mathrm{Ni}\left(\mathrm{P}^{\mathrm{Cy}}{ }_{2} \mathrm{~N}^{t-\mathrm{Bu}}{ }_{2}\right)_{2}$ in benzonitrile $\left(\mathrm{Ni}\left(\mathrm{P}^{\mathrm{Cy}}{ }_{2} \mathrm{~N}^{t-\mathrm{Bu}}{ }_{2}\right)_{2}\right.$ is not soluble in acetonitrile). Under these conditions, an equilibrium is observed (eq 1 ) for protonation of
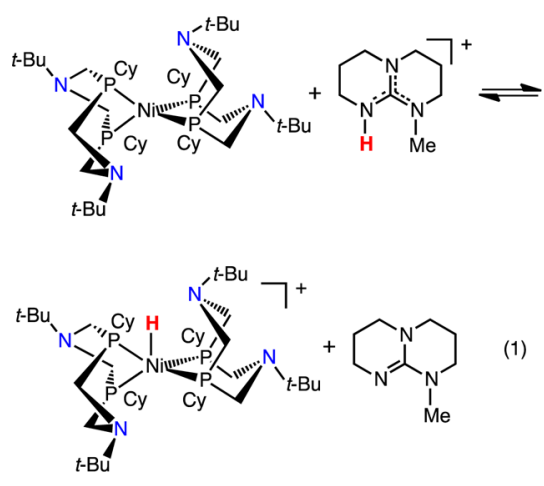

$\mathrm{Ni}\left(\mathrm{P}^{\mathrm{Cy}}{ }_{2} \mathrm{~N}^{t-\mathrm{Bu}}\right)_{2}$ to give the nickel hydride complex $[\mathrm{NiH}-$ $\left.\left(\mathrm{P}^{\mathrm{Cy}}{ }_{2} \mathrm{~N}^{t-\mathrm{Bu}}{ }_{2}\right)_{2}\right]^{+}$. The two species are observed in the ${ }^{31} \mathrm{P}\left\{{ }^{1} \mathrm{H}\right\}$ NMR spectrum at 13.0 and $7.3 \mathrm{ppm}$, respectively; no other resonances are observed. Most of the ${ }^{1} \mathrm{H}$ NMR spectrum of this solution was obscured by the protons of the benzonitrile solvent, but a broad resonance observed at $-13.5 \mathrm{ppm}$ is attributed to the hydride resonance of $\left[\mathrm{NiH}\left(\mathrm{P}_{2}^{\mathrm{Cy}} \mathrm{N}^{\mathrm{t}-\mathrm{Bu}}{ }_{2}\right)_{2}\right]^{+}$. The ratios of these two complexes were measured by integration of the ${ }^{31} \mathrm{P}\left\{{ }^{1} \mathrm{H}\right\}$ NMR spectrum, and an equilibrium constant of $K_{\mathrm{eq}}=9( \pm 6)$ was calculated from this data. This equilibrium constant and a $\mathrm{p} K_{\mathrm{a}}$ value of 25.5 for $[\mathrm{H}-$ $\mathrm{MTBD}] \mathrm{BF}_{4}$ in acetonitrile ${ }^{67}$ were used to determine a $\mathrm{pK} K_{\mathrm{al}}$ value of $24.6( \pm 0.3)$ for $\left[\mathrm{NiH}\left(\mathrm{P}_{2}^{\mathrm{Cy}}{ }_{2} \mathrm{~N}_{2}^{t-\mathrm{Bu}}\right)_{2}\right]^{+}$(Scheme 2$)$.

Scheme 2. Protonation Equilibria for $\mathrm{Ni}\left(\mathrm{P}^{\mathrm{Cy}}{ }_{2} \mathrm{~N}^{t-\mathrm{Bu}}{ }_{2}\right)_{2}$ and $\left[\mathrm{NiH}\left(\mathrm{P}_{2}^{\mathrm{Cy}} \mathrm{N}^{t-\mathrm{Bu}}\right)_{2}\right]^{+a}$

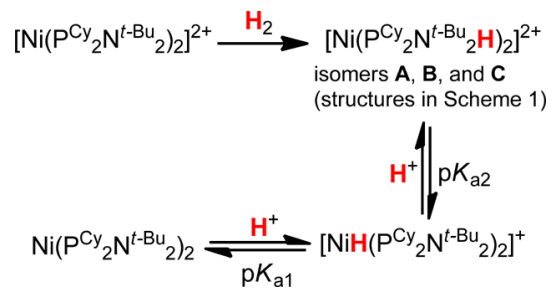

${ }^{a}$ The structures of isomers $\mathbf{A}, \mathbf{B}$, and $\mathbf{C}$ are shown in Scheme 1 .

Previous studies have shown that relative $\mathrm{p} K_{\mathrm{a}}$ values for similar complexes in acetonitrile and benzonitrile are the same within experimental error. ${ }^{68}$ As a cross check, the same experiments were repeated using a buffered solution of 1,8-diazabicyclo[5.4.0] undec-7-ene (DBU) and its protonated analogue [H$\mathrm{DBU}] \mathrm{BF}_{4}$. With this buffer, and using a $\mathrm{p} K_{\mathrm{a}}$ of 24.34 for [H$\mathrm{DBU}] \mathrm{BF}_{4}$ in acetonitrile, ${ }^{67}$ a $\mathrm{pK} \mathrm{a}_{\mathrm{a}}$ value of 24.7 was determined for $\left[\mathrm{NiH}\left(\mathrm{P}^{\mathrm{Cy}}{ }_{2} \mathrm{~N}^{t-\mathrm{Bu}}{ }_{2}\right)_{2}\right]^{+}$in good agreement with the value obtained using MTBD/[H-MTBD $]^{+}$.

The acidity of hydrogen addition products $\left(\mathrm{p} K_{\mathrm{a} 2}\right.$ in Scheme 2), A-C, were measured by the addition of hydrogen to $\left[\mathrm{Ni}\left(\mathrm{P}^{\mathrm{Cy}}{ }_{2} \mathrm{~N}^{t-\mathrm{Bu}}\right)_{2}\right]^{2+}$ in acetonitrile, followed by addition of the base 4-dimethylaminopyridine (DMAP) to give an equilibrium between the three isomers and the nickel hydride. The concentrations of the $\mathrm{Ni}$ complexes were determined by ${ }^{31} \mathrm{P}\left\{{ }^{1} \mathrm{H}\right\}$ NMR spectroscopy, and the concentrations of the protonated and unprotonated DMAP were measured by ${ }^{1} \mathrm{H}$ NMR spectroscopy. The chemical shift of the DMAP resonances is a weighted average of the values for the respective pure acid and base because of rapid exchange on the NMR time scale. The equilibrium constants between the hydride and isomers $\mathbf{A}, \mathbf{B}$, and $\mathbf{C}$, are $K_{\mathrm{A} \text { eq }}=240( \pm 20), K_{\mathrm{B}, \mathrm{eq}}=70( \pm 10)$ and $K_{\mathrm{C} \text { eq }}=31( \pm 6)$, respectively. Using a $\mathrm{p} K_{\mathrm{a}}$ value of 17.95 for [H-DMAP] $\mathrm{BF}_{4}$ in acetonitrile, ${ }^{67}$ the $\mathrm{pK}_{\mathrm{a}}$ values of isomers A, B, and C are 15.6, 16.1, and 16.5, respectively. Weighting the $\mathrm{p} K_{\mathrm{a}}$ values of the isomers with their relative concentrations gives an average $\mathrm{p} K_{\mathrm{a} 2}$ of 16.5 . These measurements were also cross-checked by performing similar experiments with 2,6lutidinium ( $\mathrm{p} K_{\mathrm{a}}$ of 14.13 in acetonitrile), ${ }^{67}$ which gave similar $\mathrm{p} K_{\mathrm{a}}$ values (see Experimental Section).

Thermodynamic Data for Hydrogen Addition to $\left[\mathrm{Ni}\left(\mathrm{P}^{\mathrm{Cy}}{ }_{2} \mathrm{~N}^{t-\mathrm{Bu}}{ }_{2}\right)_{2}\right]\left(\mathrm{BF}_{4}\right)_{2}$. The $\mathrm{p} K_{\mathrm{a} 1}$ value of $\left[\mathrm{NiH}\left(\mathrm{P}^{\mathrm{Cy}}{ }_{2} \mathrm{~N}^{t-\mathrm{Bu}}{ }_{2}\right)_{2}\right]^{+}$ and the redox potentials of $\left[\mathrm{Ni}\left(\mathrm{P}^{\mathrm{Cy}}{ }_{2} \mathrm{~N}^{t-\mathrm{Bu}}{ }_{2}\right)_{2}\right]^{2+}$, together with the known value in acetonitrile for the two-electron reduction of a proton to a hydride, ${ }^{69}$ were used in the thermodynamic cycle shown in Scheme 3 to determine the hydride donor 
Scheme 3. Determination of the Hydride Donor Ability of $\left[\mathrm{NiH}\left(\mathrm{P}^{\mathrm{Cy}}{ }_{2} \mathrm{~N}^{t-\mathrm{Bu}}{ }_{2}\right)_{2}\right]^{+}$

\begin{tabular}{ll}
{$\left[\mathrm{NiH}\left(\mathrm{P}_{2}{ }_{2} \mathrm{~N}^{\mathrm{tBu}}{ }_{2}\right)_{2}\right]^{+} \longrightarrow\left[\mathrm{Ni}\left(\mathrm{PCy}_{2} \mathrm{~N}^{\mathrm{tBu}}{ }_{2}\right)_{2}\right]+\mathrm{H}^{+}$} & $\Delta G^{\circ}=1.37\left(\mathrm{pK} K_{\mathrm{a} 1}\right)=33.8 \mathrm{kcal} / \mathrm{mol}$ \\
{$\left[\mathrm{Ni}\left(\mathrm{P}^{\mathrm{Cy}}{ }_{2} \mathrm{~N}^{\mathrm{tBu}}{ }_{2}\right)_{2}\right] \longrightarrow\left[\mathrm{Ni}\left(\mathrm{P}_{2}^{\mathrm{Cy}}{ }_{2} \mathrm{~N}^{\mathrm{tBu}}{ }_{2}\right)_{2}\right]^{2+}+2 \mathrm{e}^{-}$} & $\Delta G^{\circ}=46.1 \mathrm{E}^{\circ}(\mathrm{II} / 0)=-52.1 \mathrm{kcal} / \mathrm{mol}$ \\
& $\Delta G^{\circ}=46.1 \mathrm{E}^{\circ}\left(\mathrm{H}^{+} / \mathrm{H}^{-}\right)=79.6 \mathrm{kcal} / \mathrm{mol}$ \\
\hline$\left[\mathrm{NiH}\left(\mathrm{P}^{\mathrm{Cy}}{ }_{2} \mathrm{~N}^{\mathrm{tBu}}{ }_{2}\right)_{2}\right]^{+} \longrightarrow\left[\mathrm{Ni}\left(\mathrm{P}^{-}{ }_{2} \mathrm{~N}^{\mathrm{tBu}}{ }_{2}\right)_{2}\right]^{2+}+\mathrm{H}^{-}$ & $\Delta G^{\circ}{ }_{\mathrm{H}^{-}}=61.3 \mathrm{kcal} / \mathrm{mol}$
\end{tabular}

ability $\left(\Delta G^{\circ}{ }_{\mathrm{H}^{-}}\right)$of $61.3 \mathrm{kcal} / \mathrm{mol}$ for $\left[\mathrm{NiH}\left(\mathrm{P}^{\mathrm{Cy}}{ }_{2} \mathrm{~N}^{\mathrm{t}-\mathrm{Bu}}{ }_{2}\right)_{2}\right]^{+} .8$ The value of $\Delta G^{\circ} \mathrm{H}^{-}$for this complex is comparable to that of $\left[\mathrm{NiH}\left(\mathrm{P}^{\mathrm{Cy}}{ }_{2} \mathrm{~N}_{2}^{\mathrm{Bn}}\right)_{2}\right]^{+}$, which has cyclohexyl substituents on the phosphorus and benzyl groups on the amine $\left(\Delta G^{\circ}{ }_{H^{-}}=60.7\right.$ $\mathrm{kcal} / \mathrm{mol}$ ), and is larger (indicating a weaker hydride donor) than analogous complexes with phenyls on the phosphorus $\left(\Delta G^{\circ} \mathrm{H}^{-}=57.1-59.0 \mathrm{kcal} / \mathrm{mol}\right){ }^{8}$ Previous studies have shown that the steric size of the substituent on the phosphorus is an important factor influencing hydride donor ability, and in some cases they can override electronic effects. ${ }^{70,71}$

The hydride donor ability $\left(\Delta G^{\circ}{ }_{\mathrm{H}^{-}}\right)$of $61.3 \mathrm{kcal} / \mathrm{mol}$ for $\left[\mathrm{NiH}\left(\mathrm{P}_{2}^{\mathrm{Cy}} \mathrm{N}^{t-\mathrm{Bu}}\right)_{2}\right]^{+}$and the $\mathrm{p} K_{\mathrm{a} 2}$ value of 16.5 (weighted average for the three isomers, as described above) for the doubly protonated $\mathrm{Ni}^{0}$ complex can be used along with the free energy for the heterolytic cleavage of hydrogen in acetonitrile $^{69,72}$ to determine the free energy of $-7.9 \mathrm{kcal} / \mathrm{mol}$ (Scheme 4) associated with the addition of hydrogen to

Scheme 4. Determination of the Free Energy of $\mathrm{H}_{2}$ addition to $\left[\mathrm{Ni}\left(\mathrm{P}^{\mathrm{Cy}}{ }_{2} \mathrm{~N}^{t-\mathrm{Bu}}{ }_{2}\right)_{2}\right]^{2+}$

\begin{tabular}{ll}
{$\left[\mathrm{Ni}\left(\mathrm{P}^{\mathrm{Cy}}{ }_{2} \mathrm{~N}^{\mathrm{tBu}}{ }_{2}\right)_{2}\right]^{2+}+\mathrm{H}^{-} \longrightarrow\left[\mathrm{NiH}\left(\mathrm{P}^{\mathrm{Cy}}{ }_{2} \mathrm{~N}^{\mathrm{tBu}}{ }_{2}\right)_{2}\right]^{+}$} & $\Delta G^{\circ}{ }_{\mathrm{H}^{-}}=-61.3 \mathrm{kcal} / \mathrm{mol}$ \\
{$\left[\mathrm{NiH}\left(\mathrm{P}^{\mathrm{Cy}}{ }_{2} \mathrm{~N}^{\mathrm{HBu}}{ }_{2}\right)_{2}\right]^{+}+\mathrm{H}^{+} \longrightarrow\left[\mathrm{Ni}\left(\mathrm{P}^{\mathrm{Cy}}{ }_{2} \mathrm{~N}^{\mathrm{tBu}}{ }_{2} \mathrm{H}\right)_{2}\right]^{2+}$} & $\Delta G^{\circ}=-1.37\left(\mathrm{pK} \mathrm{a}_{2}\right)=-22.6 \mathrm{kcal} / \mathrm{mol}$ \\
$\mathrm{H}_{2} \longrightarrow \mathrm{H}^{+}+\mathrm{H}^{-}$ & $\Delta G^{\circ}=76.0 \mathrm{kcal} / \mathrm{mol}$ \\
\hline$\left[\mathrm{Ni}\left(\mathrm{P}^{\mathrm{Cy}}{ }_{2} \mathrm{~N}^{\mathrm{tBu}}{ }_{2}\right)_{2}\right]^{2+}+\mathrm{H}_{2} \longrightarrow\left[\mathrm{Ni}\left(\mathrm{PCy}_{2} \mathrm{~N}^{\mathrm{tBu}}{ }_{2} \mathrm{H}\right)_{2}\right]^{2+}$ & $\Delta G^{\circ}{ }_{\mathrm{H} 2}=-7.9 \mathrm{kcal} / \mathrm{mol}$
\end{tabular}

$\left[\mathrm{Ni}\left(\mathrm{P}^{\mathrm{Cy}}{ }_{2} \mathrm{~N}^{t-\mathrm{Bu}}{ }_{2}\right)_{2}\right]^{2+}$. This is significantly more negative than the previously studied hydrogen oxidation complex, [Ni$\left.\left(\mathrm{P}_{2}^{\mathrm{Cy}} \mathrm{N}_{2}^{\mathrm{Bn}}\right)_{2}\right]^{2+}$, which has a free energy of hydrogen addition of $-3.1 \mathrm{kcal} / \mathrm{mol}^{8,48}$

Electrochemical Studies and Catalytic Oxidation of $\mathrm{H}_{2}$. The cyclic voltammogram of $\left[\mathrm{Ni}\left(\mathrm{P}^{\mathrm{Cy}}{ }_{2} \mathrm{~N}^{t-\mathrm{Bu}}{ }_{2}\right)_{2}\right]\left(\mathrm{BF}_{4}\right)_{2}$ in benzonitrile exhibits $\mathrm{Ni}^{\mathrm{II} / \mathrm{I}}$ and $\mathrm{Ni}^{\mathrm{I} / 0}$ redox couples at -0.81 and $-1.45 \mathrm{~V}\left(\Delta E_{\mathrm{p}}=82\right.$ and $60 \mathrm{mV}$ at a scan rate of $\left.50 \mathrm{mV} / \mathrm{s}\right)$, respectively, versus the $\mathrm{Cp}_{2} \mathrm{Fe}^{+/ 0}$ couple. In acetonitrile, the $\mathrm{Ni}^{\mathrm{II} / \mathrm{I}}$ couple for $\left[\mathrm{Ni}\left(\mathrm{P}^{\mathrm{Cy}}{ }_{2} \mathrm{~N}^{\mathrm{t}-\mathrm{Bu}}{ }_{2}\right)_{2}\right]^{2+}$ is observed at $-0.77 \mathrm{~V}$ vs $\mathrm{Cp}_{2} \mathrm{Fe}^{+/ 0}$ and is shown as the black trace in Figure 3. Purging this solution with hydrogen results in an immediate color change of this solution from red to colorless and is associated with the formation of isomer $\mathbf{A}$, which persists for hours as the major product in the absence of water. A cyclic voltammogram of a solution of $\left[\mathrm{Ni}\left(\mathrm{P}^{\mathrm{Cy}}{ }_{2} \mathrm{~N}^{t-\mathrm{Bu}}{ }_{2}\right)_{2}\right]^{2+}$ purged with hydrogen is shown in Figure 3 as the red trace. The $\mathrm{Ni}^{\mathrm{I} / 0}$ couple is quasireversible, and occurs at $E_{1 / 2}(\mathrm{I} / 0)=-0.36 \mathrm{~V}\left(\Delta E_{\mathrm{p}}=116\right.$ $\mathrm{mV}$ and $i_{\text {cathodic }} / i_{\text {anodic }}=1.3$ at a scan rate of $\left.50 \mathrm{mV} / \mathrm{s}\right)$. As discussed above, the addition of water to solutions of $\mathbf{A}$ promotes its isomerization to endo-exo (B), and exo-exo (C), isomers. Ten equivalents of water with respect to the $\mathrm{Ni}$ complex were added to a solution to facilitate isomerization of A to form $\mathbf{B}$ and $\mathbf{C}$, and an NMR spectrum acquired of the solution after $8 \mathrm{~h}$ confirmed the presence of all three isomers. The cyclic voltammogram of this solution displayed two $\mathrm{Ni}^{\mathrm{I} / 0}$ quasireversible and one irreversible oxidation couples assigned to the three isomers (see the blue trace in Figure 3). The quasireversible oxidation couple with $E_{1 / 2}(\mathrm{I} / 0)=-0.48 \mathrm{~V}$ (est.

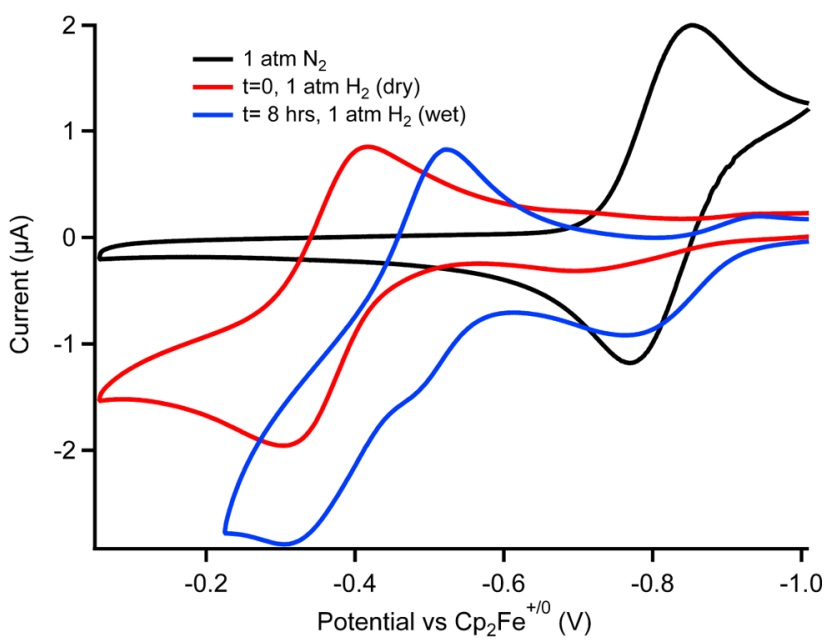

Figure 3. Cyclic voltammogram of a $1.8 \mathrm{mM}$ solution of $\left[\mathrm{Ni}\left(\mathrm{P}^{\mathrm{Cy}}{ }_{2} \mathrm{~N}^{t-\mathrm{Bu}}{ }_{2}\right)_{2}\right]\left(\mathrm{BF}_{4}\right)_{2}$ in acetonitrile under nitrogen (black), under $1 \mathrm{~atm}$ hydrogen (red), and $8 \mathrm{~h}$ after the addition of 10 equiv of water (blue). Conditions: scan rate $=50 \mathrm{mV} / \mathrm{s}, 0.2 \mathrm{M} \mathrm{Bu}_{4} \mathrm{NPF}_{6}$, glassy carbon working electrode. Potentials are referenced to the $\mathrm{Cp}_{2} \mathrm{Fe}^{+/ 0}$ couple.

$\Delta E_{\mathrm{p}}=55 \mathrm{mV}$ and $i_{\text {cathodic }} / i_{\text {anodic }}=1.5$ at a scan rate of $50 \mathrm{mV} / \mathrm{s}$ ) is assigned to isomer $\mathbf{B}$, and the irreversible couple with $E_{\mathrm{p}}(\mathrm{I} / 0)$ $=-0.75 \mathrm{~V}$ is assigned to isomer $\mathbf{C}$. The oxidation potential of isomer $\mathbf{A}$ is $120 \mathrm{mV}$ positive of the oxidation potential of isomer $\mathbf{B}$ and $530 \mathrm{mV}$ positive of the potential for isomer $\mathbf{C}$. Similar separations of the redox potentials were found previously for $\left[\mathrm{Ni}\left(\mathrm{P}^{t-\mathrm{Bu}}{ }_{2} \mathrm{~N}^{\mathrm{Bn}}{ }_{2} \mathrm{H}\right)_{2}\right]^{2+} \cdot{ }^{73}$

Effect of Water on the Catalytic Rate of Hydrogen Oxidation. Recent results in our laboratory with related $\left[\mathrm{Ni}\left(\mathrm{P}^{\mathrm{Ph}}{ }_{2} \mathrm{~N}^{\mathrm{R}}{ }_{2}\right)_{2}\right]^{2+}$ complexes demonstrate increases in the rate of electrocatalytic proton reduction upon addition of water to acetonitrile solutions. ${ }^{9,12,15,74}$ These rate accelerations range from $20 \%{ }^{12}$ to over a factor of $60 .{ }^{15}$ To determine whether water might have an effect on the opposite reaction, oxidation of hydrogen, we examined $\left[\mathrm{Ni}^{\mathrm{I}}\left(\mathrm{P}^{\mathrm{Cy}}{ }_{2} \mathrm{~N}^{t-\mathrm{Bu}}{ }_{2}\right)_{2}\right]\left(\mathrm{BF}_{4}\right)$ for changes in catalytic activity upon addition of water. Water is significantly more miscible with acetonitrile than benzonitrile, so the former was used in these studies. The $E_{1 / 2}$ potentials of the $\mathrm{Ni}^{\mathrm{II} / \mathrm{I}}$ and $\mathrm{Ni}^{\mathrm{I} / 0}$ couples in acetonitrile are observed at -0.77 and $-1.42 \mathrm{~V}$, respectively.

The cyclic voltammogram of $\left[\mathrm{Ni}^{\mathrm{I}}\left(\mathrm{P}^{\mathrm{Cy}}{ }_{2} \mathrm{~N}^{t-\mathrm{Bu}}{ }_{2}\right)_{2}\right]$ in acetonitrile under an atmosphere of nitrogen (black trace) is shown in Figure 4. The cyclic voltammogram of the same solution under 1 atm of hydrogen is shown as the red trace in Figure 4. Upon oxidation to $\mathrm{Ni}^{\mathrm{II}}$, the complex reacts with hydrogen to form the doubly protonated $\mathrm{Ni}^{0}$ complex, which displays an oxidation wave at $E_{\mathrm{p}}=-0.36 \mathrm{~V}$, as discussed above. On the return scan, the wave associated with the (II/I) couple of $\left.\left[\mathrm{Ni}^{\mathrm{I}}\left(\mathrm{P}^{\mathrm{Cy}}{ }_{2} \mathrm{~N}^{t-\mathrm{Bu}}\right)_{2}\right)_{2}\right]^{+}$is absent. Addition of $\mathrm{NEt}_{3}$ results in an increase in the anodic current observed at $-0.77 \mathrm{~V}$. The plateau shape of this wave and the magnitude of the current enhancement indicate that this is a catalytic wave corresponding to the oxidation of $\mathrm{H}_{2}$. No further increase in catalytic current was observed above a concentration of $17 \mathrm{mM} \mathrm{NEt}_{3}$ (green trace). Recent experimental measurements of open circuit potentials at a platinum electrode provide an accurate evaluation of the thermodynamic potentials for oxidation and production of hydrogen under different conditions. ${ }^{75}$ On the basis of these measurements, the reversible potential for $\mathrm{H}_{2}$ 


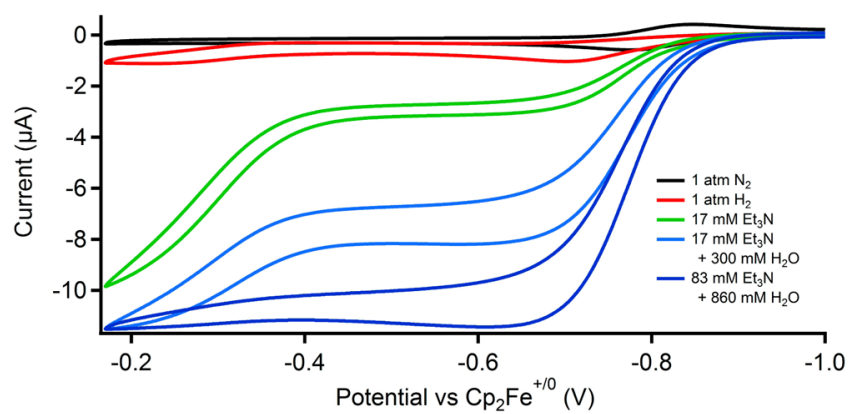

Figure 4. Cyclic voltammogram of a $1.0 \mathrm{mM}$ solution of $\left[\mathrm{Ni}^{\mathrm{I}}\left(\mathrm{P}_{2}{ }_{2} \mathrm{~N}^{t-\mathrm{Bu}}{ }_{2}\right)_{2}\right]\left(\mathrm{BF}_{4}\right)$ in acetonitrile under nitrogen (black), under hydrogen (red), with $17 \mathrm{mM} \mathrm{NEt}_{3}$ (green), $17 \mathrm{mM} \mathrm{NEt}_{3}$ and $300 \mathrm{mM}$ $\mathrm{H}_{2} \mathrm{O}$ (light blue), and $83 \mathrm{mM} \mathrm{NEt}_{3}$ and $860 \mathrm{mM} \mathrm{H}_{2} \mathrm{O}$ (dark blue). Conditions: scan rate $=50 \mathrm{mV} / \mathrm{s}, 0.2 \mathrm{M} \mathrm{Bu}_{4} \mathrm{NPF}_{6}$, glassy carbon working electrode, $23{ }^{\circ} \mathrm{C}$. Potentials are referenced to the $\mathrm{Cp}_{2} \mathrm{Fe}^{+/ 0}$ couple.

oxidation $(1.0 \mathrm{~atm})$ in the presence of $17 \mathrm{mM} \mathrm{NEt}_{3}$ in acetonitrile is $-1.31 \mathrm{~V}$, indicating that the overpotential (as measured at the half-height of the catalytic wave) under these conditions is about $0.54 \mathrm{~V}$. However, we did not attempt to minimize the overpotential by studying bases of varying strength.

Subsequent cyclic voltammograms recorded with increasing concentrations of water $(44-860 \mathrm{mM})$ displayed an increase in the catalytic current at $-0.77 \mathrm{~V}$. Successive increases in the concentrations of $\mathrm{NEt}_{3}$ and water led to an increase in current until the concentration was $83 \mathrm{mM} \mathrm{NEt}_{3}$ and $860 \mathrm{mM} \mathrm{H}_{2} \mathrm{O}$ (see Supporting Information). Higher concentrations of water and $\mathrm{NEt}_{3}$ did not result in any further increase in current, indicating that the catalyst is operating under substrate concentration independent conditions (zero-order in base). Changes in catalyst concentration from 0.3 to $0.8 \mathrm{mM}$ do not result in changes in the measured $i_{\mathrm{cat}} / i_{\mathrm{p}}$, indicating the catalyst is not operating under hydrogen-limited conditions. The oxidative current $\left(i_{\text {cat }}\right)$ for the $\mathrm{Ni}^{\mathrm{II} / \mathrm{I}}$ couple under $1.0 \mathrm{~atm}$ of hydrogen, $83 \mathrm{mM} \mathrm{NEt}_{3}$, and $860 \mathrm{mM} \mathrm{H}_{2} \mathrm{O}$ is 22 times larger than the current $\left(i_{\mathrm{p}}\right)$ observed for the $\mathrm{Ni}^{\mathrm{II} / \mathrm{I}}$ couple in the absence of hydrogen, base, and water. The ratio $\left(i_{\text {cat }} / i_{\mathrm{p}}\right)$ of the catalytic current under substrate (base) independent conditions divided by the peak current under noncatalytic conditions can be used to calculate (eq 2) a turnover frequency of $45 \mathrm{~s}^{-1}$ under 1.0 atm of $\mathrm{H}_{2}$. This value is close to the value of $50 \mathrm{~s}^{-1}$ reported previously using triethylamine as the base in benzonitrile, although the prior study was not performed under rigorously dry conditions. ${ }^{50}$ In eq $2, R$ is the gas constant, $T$ is the temperature in $\mathrm{K}, F$ is the Faraday constant, $v$ is the scan rate in $\mathrm{V} / \mathrm{s}$, and $k_{\text {obs }}$ is the observed rate constant, or turnover frequency. $6,13,76-78$

$$
\frac{i_{\mathrm{cat}}}{i_{\mathrm{p}}}=\frac{n}{0.4463} \sqrt{\frac{R T k_{\mathrm{obs}}}{F v}}
$$

In addition to the increase in current observed for the wave at $-0.77 \mathrm{~V}$, it can also be seen that there is enhanced current at $-0.36 \mathrm{~V}$ in the presence of $\mathrm{NEt}_{3}$ with no added water (green trace in Figure 4), indicating a second catalytic pathway for $\mathrm{H}_{2}$ oxidation that involves $\mathrm{Ni}^{0}$ isomer $\mathbf{A}$, which oxidizes at a much more positive potential. This pathway is disfavored upon addition of water.
Effect of Base Size on Catalytic Rate of Hydrogen Oxidation. We also examined the effect of base size on the catalytic rate by using $t$-butylamine and $n$-butylamine (see Figure 5 for cyclic voltammograms of the latter). Their conjugate acids have nearly identical $\mathrm{p} K_{\mathrm{a}}$ values of 18.1 and 18.3 , respectively, in acetonitrile; for comparison, the $\mathrm{p} K_{\mathrm{a}}$ value

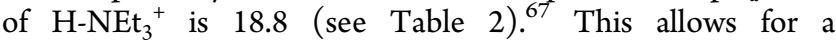

Table 2. Turnover Frequencies (TOF, $\mathrm{s}^{-1}$ ) at $23{ }^{\circ} \mathrm{C}$ for Electrocatalytic Oxidation of Hydrogen (1 atm) by $\left[\mathrm{Ni}\left(\mathrm{P}^{\mathrm{Cy}}{ }_{2} \mathrm{~N}^{t-\mathrm{Bu}}\right)_{2}\right]^{2+}$ Using Three Amines in Dry Acetonitrile, and in Acetonitrile with Added Water

\begin{tabular}{lccc}
\multicolumn{1}{c}{ base } & $\mathrm{pK}_{\mathrm{a}}^{a}$ & TOF $\left(\mathrm{s}^{-1}\right)$, dry & TOF $\left(\mathrm{s}^{-1}\right)$, with $\mathrm{H}_{2} \mathrm{O}\left(\mathrm{mM} \mathrm{H}_{2} \mathrm{O}\right)$ \\
$n-\mathrm{BuNH}_{2}$ & 18.3 & 50 & $58(128)$ \\
$t-\mathrm{BuNH}_{2}$ & 18.1 & 2 & $43(360)$ \\
$\mathrm{NEt}_{3}$ & 18.8 & 3 & $45(860)$
\end{tabular}

${ }^{a} \mathrm{p} K_{\mathrm{a}}$ values (MeCN solvent) are for those of the corresponding conjugate acids of the bases.

comparison of the effect of base size, because the thermodynamic driving force for catalysis is nearly the same with all of these amine bases. A plot of $i_{\text {cat }} / i_{\mathrm{p}}$ as a function of the concentration of $n$-butylamine is shown in Figure 6. The value

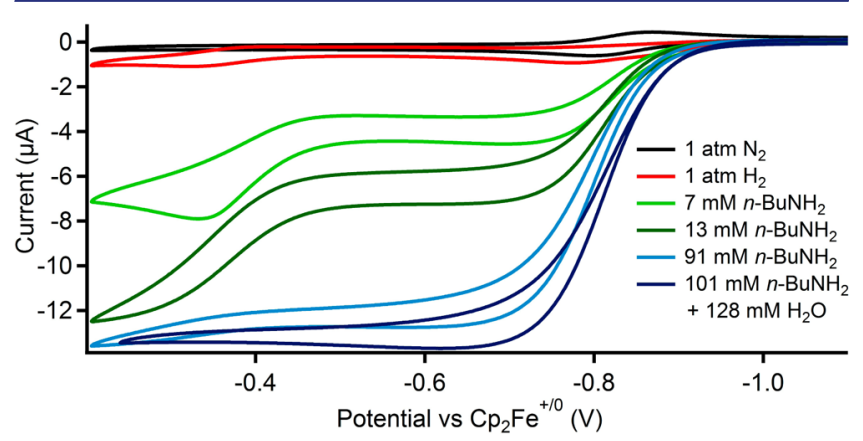

Figure 5. Cyclic voltammogram of a $0.62 \mathrm{mM}$ solution of $\left[\mathrm{Ni}\left(\mathrm{P}^{\mathrm{Cy}}{ }_{2} \mathrm{~N}^{t-\mathrm{Bu}}{ }_{2}\right)_{2}\right]\left(\mathrm{BF}_{4}\right)_{2}$ in acetonitrile under nitrogen (black), under hydrogen (red), varying amounts of $n-\mathrm{BuNH}_{2}$ (green and light blue traces), and $101 \mathrm{mM} n-\mathrm{BuNH}_{2}$ and $128 \mathrm{mM} \mathrm{H}_{2} \mathrm{O}$ (dark blue). Conditions: scan rate $=50 \mathrm{mV} / \mathrm{s}, 0.2 \mathrm{M} \mathrm{Bu}_{4} \mathrm{NPF}_{6}$, glassy carbon working electrode, $23{ }^{\circ} \mathrm{C}$. Potentials are referenced to the $\mathrm{Cp}_{2} \mathrm{Fe}^{+/ 0}$ couple.

of $i_{\text {cat }} / i_{\mathrm{p}}$ increases with $\left[n-\mathrm{BuNH}_{2}\right]$ at low concentrations and becomes independent of base concentration at higher concentrations. Without added water, the maximum turnover

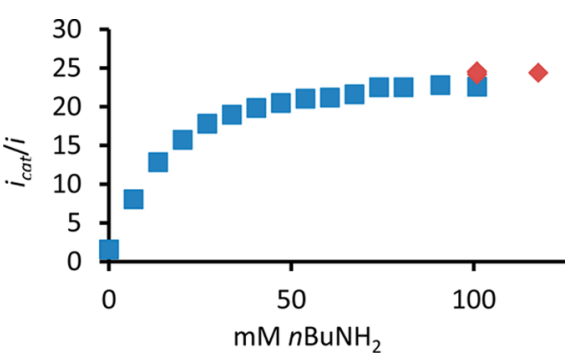

Figure 6. Plot of $i_{\text {cat }} / i_{\mathrm{p}}$ vs $\left[n-\mathrm{BuNH}_{2}\right]$ for oxidation of $\mathrm{H}_{2}$ by an 0.62 $\mathrm{mM}$ solution of $\left[\mathrm{Ni}\left(\mathrm{P}_{2}^{\mathrm{Cy}}{ }_{2} \mathrm{~N}^{t-\mathrm{Bu}}\right)_{2}\right]\left(\mathrm{BF}_{4}\right)_{2}$ in acetonitrile. Conditions: scan rate $=50 \mathrm{mV} / \mathrm{s}, 0.2 \mathrm{M} \mathrm{Bu}_{4} \mathrm{NPF}_{6}$ as supporting electrolyte, glassy carbon working electrode. Red diamonds are for experiments with 219 $\mathrm{mM} \mathrm{H}_{2} \mathrm{O}$. 
frequency obtained using $n-\mathrm{BuNH}_{2}$ as the base under $1.0 \mathrm{~atm}$ of hydrogen is $50 \mathrm{~s}^{-1}$, which is significantly larger than that observed for $t-\mathrm{BuNH}_{2}$ or $\mathrm{NEt}_{3}$. All of the rates increase upon addition of water, but the rate increase is most pronounced for the sterically hindered bases, $t-\mathrm{BuNH}_{2}$ and $\mathrm{NEt}_{3}$, which increase by more than an order of magnitude. As shown in Table 2 , the fastest rate observed for the catalyst is in the presence of both $n-\mathrm{BuNH}_{2}$ and water, $58 \mathrm{~s}^{-1}$, but this rate is only slightly (20\%) faster than that observed in the absence of water.

Reactivity of $\left[\mathrm{Ni}\left(\mathrm{P}^{\mathrm{Cy}}{ }_{2} \mathrm{~N}^{t-\mathrm{Bu}}{ }_{2}\right)_{2}\right]^{2+}$ with Carbon Monoxide. It is important to study the reaction of our catalysts with $\mathrm{CO}$ because the hydrogen used in fuel cells is typically generated by steam reforming of methane and is contaminated with $\mathrm{CO}$, which poisons platinum catalysts even at parts per million levels. The complex $\left[\mathrm{Ni}\left(\mathrm{P}^{\mathrm{Cy}}{ }_{2} \mathrm{~N}^{t-\mathrm{Bu}}{ }_{2}\right)_{2}\right]^{2+}$ in acetonitrile reacts rapidly with $\mathrm{CO}$, turning from red to orange. The ${ }^{31} \mathrm{P}\left\{{ }^{1} \mathrm{H}\right\}$ NMR spectrum displays resonances at 43 and $-15 \mathrm{ppm}$ (Figure 6). This reaction proceeds to completion under 1 atm of $\mathrm{CO}$, with no starting material or other products observed in the ${ }^{31} \mathrm{P}\left\{{ }^{1} \mathrm{H}\right\}$ NMR spectrum. The previously studied hydrogen oxidation catalyst $\left[\mathrm{Ni}\left(\mathrm{P}^{\mathrm{Cy}}{ }_{2} \mathrm{~N}_{2}^{\mathrm{Bn}}\right)_{2}\right]^{2+}$ displayed an intermediate with similar ${ }^{31} \mathrm{P}$ NMR resonances (57 and $-4 \mathrm{ppm}$ ) upon reaction with $\mathrm{CO}$, and was characterized by a single crystal Xray diffraction study. ${ }^{79}$ The proposed reaction product of $\left[\mathrm{Ni}\left(\mathrm{P}_{2}^{\mathrm{Cy}} \mathrm{N}^{t-\mathrm{Bu}}\right)_{2}\right]^{2+}$ with $\mathrm{CO}$ (shown in Figure 7 ) is expected to

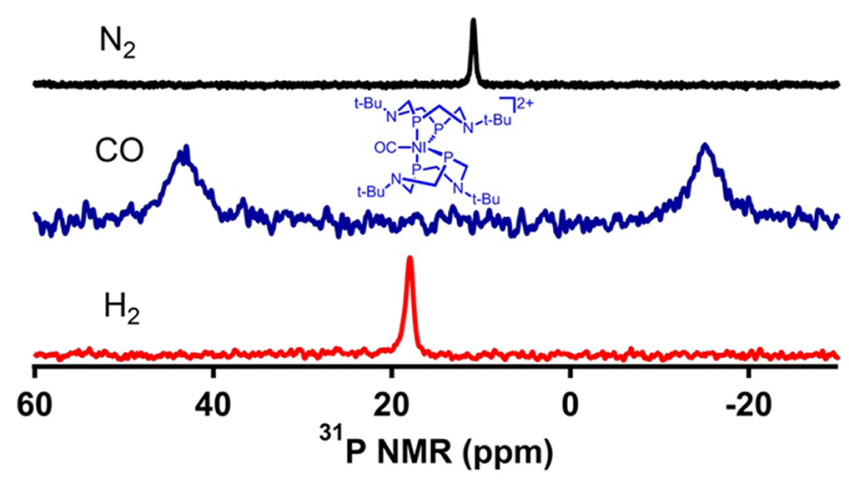

Figure 7. ${ }^{31} \mathrm{P}\left\{{ }^{1} \mathrm{H}\right\}$ NMR spectrum of $\left[\mathrm{Ni}\left(\mathrm{P}^{\mathrm{Cy}}{ }_{2} \mathrm{~N}^{t-\mathrm{Bu}}{ }_{2}\right)_{2}\right]^{2+}$ in acetonitrile under $1 \mathrm{~atm}$ of nitrogen (black), under $1 \mathrm{~atm}$ of $\mathrm{CO}$ (blue), and under $1 \mathrm{~atm}$ of hydrogen (red). The proposed structure of the CO complex is shown in the figure, with the cyclohexyls on the phosphines excluded for clarity.

be structurally similar. We were unable to obtain an X-ray crystal structure of the $\mathrm{CO}$ adduct. Although large single crystals of $\left[\mathrm{Ni}(\mathrm{CO})\left(\mathrm{P}^{\mathrm{Cy}}{ }_{2} \mathrm{~N}^{t-\mathrm{Bu}}{ }_{2}\right)_{2}\right]^{2+}$ can be grown from diffusion of $\mathrm{Et}_{2} \mathrm{O}$ into acetonitrile, the crystals were sensitive to visible light, likely resulting from $\mathrm{CO}$ loss.

Although $\left[\mathrm{Ni}\left(\mathrm{P}^{\mathrm{Cy}}{ }_{2} \mathrm{~N}^{t-\mathrm{Bu}}{ }_{2}\right)_{2}\right]^{2+}$ binds $\mathrm{CO}, \mathrm{H}_{2}$ binding is favored. When a solution of $\left[\mathrm{Ni}(\mathrm{CO})\left(\mathrm{P}^{\mathrm{Cy}}{ }_{2} \mathrm{~N}^{t-\mathrm{Bu}}{ }_{2}\right)_{2}\right]^{2+}$ is purged with hydrogen, the hydrogen addition product is the only species seen in the ${ }^{31} \mathrm{P}$ NMR spectrum, with no evidence of decomposition. Exposure of $\left[\mathrm{Ni}\left(\mathrm{P}^{\mathrm{Cy}}{ }_{2} \mathrm{~N}^{t-\mathrm{Bu}}{ }_{2}\right)_{2}\right]^{2+}$ to a $1: 1 \mathrm{mix}$ of $\mathrm{H}_{2}$ and $\mathrm{CO}$ for 10 min gives the same result; only the hydrogen addition product is observed, indicating a strong preference for $\mathrm{H}_{2}$ binding over $\mathrm{CO}$.

\section{DISCUSSION}

Previous studies have shown that $\left[\mathrm{Ni}\left(\mathrm{P}_{2}{ }_{2} \mathrm{~N}^{\mathrm{R} \prime}{ }_{2}\right)_{2}\right]^{2+}$ complexes are very active catalysts for $\mathrm{H}_{2}$ production and oxidation. ${ }^{6-13,15,16,48,50,74}$ Systematic variations of the $\mathrm{R}$ substituents on phosphorus and the $\mathrm{R}^{\prime}$ groups on $\mathrm{N}$ have been used to control the hydride donor/acceptor ability of the Ni center and the basicity of the pendant base, respectively, for hydrogen production catalysts. ${ }^{12,15,74}$ As shown in Scheme 4, increasing the hydride donor ability (decreasing $\Delta G^{\circ}{ }_{\mathrm{H}^{-}}$) and decreasing the $\mathrm{pK}$ a value (increasing the acidity) of the protonated pendant amine will favor $\mathrm{H}_{2}$ elimination. These studies demonstrated that an increase in the driving force for $\mathrm{H}_{2}$ elimination from $\left[\mathrm{Ni}\left(\mathrm{P}_{2}^{\mathrm{R}} \mathrm{N}^{\mathrm{R} \prime} \mathrm{H}\right)_{2}\right]^{2+}$ complexes correlates with an increase in the catalytic rate for $\mathrm{H}_{2}$ production. ${ }^{79}$

We have previously reported that the complex [Ni$\left.\left(\mathrm{P}^{\mathrm{Cy}}{ }_{2} \mathrm{~N}_{2}{ }_{2}\right)_{2}\right]^{2+}(\mathrm{Bn}=$ benzyl $)$ is a catalyst for hydrogen oxidation, with a turnover frequency of $10 \mathrm{~s}^{-1}$ under $1 \mathrm{~atm}$ of hydrogen. ${ }^{6}$ In an effort to increase the catalytic rate of $\mathrm{H}_{2}$ oxidation for this class of catalyst, we sought to extend the approach used for $\mathrm{H}_{2}$ production catalysts to $\mathrm{H}_{2}$ oxidation catalysts. This led us to prepare $\mathrm{Ni}^{\mathrm{II}}$ complexes containing the $\mathrm{P}^{t-\mathrm{Bu}}{ }_{2} \mathrm{~N}^{\mathrm{Bn}}{ }_{2}$ ligand. It was thought that the bulky $t$-Bu groups of this ligand would lead to $\left[\mathrm{Ni}\left(\mathrm{P}^{t-B u}{ }_{2} \mathrm{~N}_{2}^{\mathrm{Bn}}\right)_{2}\right]^{2+}$ complexes with large tetrahedral distortions from a nominally square planar geometry. Such tetrahedral distortions are correlated with a strong hydride acceptor ability for these complexes. However, the steric strain introduced by the interligand interactions between the $t-\mathrm{Bu}$ groups resulted in the formation of $\left[\mathrm{Ni}\left(\mathrm{P}^{t-\mathrm{Bu}}{ }_{2} \mathrm{~N}^{\mathrm{Bn}}{ }_{2}\right)\left(\mathrm{CH}_{3} \mathrm{CN}\right)_{2}\right]^{2+}$ containing only one diphosphine ligand, and this complex is not an active catalyst for either $\mathrm{H}_{2}$ oxidation or production. ${ }^{18}$

An alternative approach to preparing faster $\mathrm{H}_{2}$ oxidation catalysts was to increase the basicity of the pendant amine. To achieve this goal we prepared the complex $\left[\mathrm{Ni}\left(\mathrm{P}_{2}^{\mathrm{Cy}}{ }_{2} \mathrm{~N}^{t-\mathrm{Bu}}{ }_{2}\right)_{2}\right]^{2+}$ as communicated previously ${ }^{50}$ and showed that it is a very fast catalyst for hydrogen oxidation under 1 atm of hydrogen. In this paper, we provide a quantitative evaluation of the difference in the driving forces for $\mathrm{H}_{2}$ addition to $\left[\mathrm{Ni}\left(\mathrm{P}^{\mathrm{Cy}}{ }_{2} \mathrm{~N}^{\mathrm{Bn}}{ }_{2}\right)_{2}\right]^{2+}$ and $\left[\mathrm{Ni}\left(\mathrm{P}_{2}^{\mathrm{Cy}}{ }_{2} \mathrm{~N}^{t-\mathrm{Bu}}\right)_{2}\right]^{2+}$ (Table 3), report the first X-ray diffraction

Table 3. Experimentally Measured Thermodynamic Values and Catalytic Turnover Frequencies for $\left[\mathrm{Ni}\left(\mathrm{P}^{\mathrm{Cy}}{ }_{2} \mathrm{~N}_{2}{ }_{2}\right)_{2}\right]^{2+}$

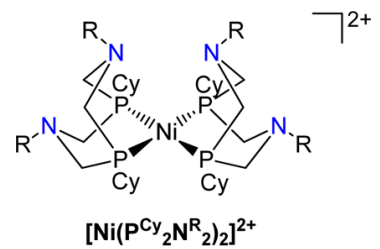

\begin{tabular}{lcccc}
\multicolumn{1}{c}{$\mathrm{R}$} & $\Delta G_{\mathrm{H}^{-}}{ }^{a}$ & $\mathrm{pK}_{\mathrm{a}}{ }^{b}(\mathrm{NR})$ & $\Delta{G^{0}{ }_{\mathrm{H}_{2}}{ }^{a}}$ & $\mathrm{TOF}\left(\mathrm{s}^{-1}\right)^{c}$ \\
benzyl $^{8}$ & -60.7 & 13.4 & -3.1 & 10 \\
$t$ - $\mathrm{Bu}$ & -61.3 & 16.5 & -7.9 & 45
\end{tabular}

${ }^{a}$ In kcal $/ \mathrm{mol} .{ }^{b}$ In acetonitrile, averaged between isomers. ${ }^{c} \mathrm{Using}_{\mathrm{Et}} \mathrm{E}$ as a base, under wet conditions.

studies of an $\mathrm{H}_{2}$ addition product of this class of $\mathrm{H}_{2}$ oxidation catalyst, discuss the energetics of addition of hydrogen to the $\mathrm{Ni}^{\mathrm{II}}$ complex, and explore the role of the pendant base and water in transferring a proton from the metal center to a base in solution.

We previously reported the synthesis and structural characterization of the $\mathrm{Ni}^{\mathrm{II}}$ complex, $\left[\mathrm{Ni}\left(\mathrm{P}^{\mathrm{Cy}}{ }_{2} \mathrm{~N}^{t-\mathrm{Bu}}{ }_{2}\right)_{2}\right]^{2+}$, which exhibited a tetrahedrally distorted square planar geometry. ${ }^{50}$ In this work, we report the synthesis of the corresponding $\mathrm{Ni}^{0}$ and $\mathrm{Ni}^{\mathrm{I}}$ complexes. Thus the complete series of complexes of the oxidation states $\mathrm{Ni}^{\mathrm{II}}, \mathrm{Ni}^{\mathrm{I}}$, and $\mathrm{Ni}^{0}$, has now 
been isolated and characterized. The structural studies of $\left[\mathrm{Ni}\left(\mathrm{P}^{\mathrm{Cy}}{ }_{2} \mathrm{~N}^{t-\mathrm{Bu}}{ }_{2}\right)_{2}\right]^{2+}$ and $\mathrm{Ni}\left(\mathrm{P}^{\mathrm{Cy}}{ }_{2} \mathrm{~N}^{t-\mathrm{Bu}}{ }_{2}\right)_{2}$ together with previous studies of $\left[\mathrm{Ni}\left(\mathrm{P}^{t-\mathrm{Bu}}{ }_{2} \mathrm{~N}^{\mathrm{Bn}}\right)_{2}\right]^{+}$and $\mathrm{Ni}\left(\mathrm{P}^{t-\mathrm{Bu}}{ }_{2} \mathrm{~N}^{\mathrm{Bn}}{ }_{2}\right)_{2}$ indicate that there are two major structural changes that occur upon reduction of these complexes, an increase in the dihedral angle between the two diphosphine ligands by approximately $60^{\circ}$ upon reduction from $\mathrm{Ni}^{\mathrm{II}}$ to $\mathrm{Ni}^{\mathrm{I}}$, and a contraction of the $\mathrm{Ni}-\mathrm{P}$ bond distance by nearly $0.1 \AA$ upon reduction from $\mathrm{Ni}^{\mathrm{I}}$ to $\mathrm{Ni}^{0}$.

The reaction of $\left[\mathrm{Ni}\left(\mathrm{P}^{\mathrm{Cy}}{ }_{2} \mathrm{~N}^{t-\mathrm{Bu}}{ }_{2}\right)_{2}\right]^{2+}$ with $\mathrm{H}_{2}$ results in the formation of the doubly protonated $\mathrm{Ni}^{0}$ product that exists in the form of three isomers, $\mathbf{A}, \mathbf{B}$, and $\mathbf{C}$, as shown in Scheme 1 . Similar isomers have been reported previously in the reaction of $\left[\mathrm{Ni}\left(\mathrm{P}^{\mathrm{Cy}}{ }_{2} \mathrm{~N}^{\mathrm{Bn}}{ }_{2}\right)_{2}\right]^{2+}$ with $\mathrm{H}_{2}$, and their structures were deduced by extensive ${ }^{1} \mathrm{H},{ }^{31} \mathrm{P}$, and ${ }^{15} \mathrm{~N}$ NMR studies. ${ }^{7,64}$ However, we had previously been unable to grow suitable crystals for X-ray diffraction studies to provide additional structural information. The X-ray diffraction study of isomer B, (Figure 2), is of special interest because it exhibits both endo protonation and exo protonation of the ligands. The distance between the two $\mathrm{N}$ atoms of the exo protonated or "pinched" ligand is $2.69 \AA$, consistent with a $\mathrm{N} \cdots \mathrm{H}-\mathrm{N}$ hydrogen bond. DFT calculations performed on the analogous complex with the $\mathrm{P}^{\mathrm{Cy}}{ }_{2} \mathrm{~N}^{\mathrm{Bn}}{ }_{2}$ ligand gave a calculated $\mathrm{N}-\mathrm{N}$ distance of $2.61 \AA{ }^{64}$ These calculations also suggest that the bridging proton is located in an asymmetric position, being closer to one $\mathrm{N}$ than the other. However, the triplet pattern observed for the proton resonance for the ${ }^{15} \mathrm{~N}$ labeled $\left[\mathrm{Ni}\left(\mathrm{P}^{\mathrm{Cy}}{ }_{2} \mathrm{~N}^{\mathrm{Bn}}{ }_{2} \mathrm{H}\right)_{2}\right]^{2+}$ complex is consistent with a dynamic process in which this proton moves back and forth between the two $\mathrm{N}$ atoms of the pinched ligand. The $\mathrm{Ni}-$ $\mathrm{N} 3$ distance for the endo protonated ligand of isomer $\mathbf{B}$ in Figure 2 is $3.31 \AA$, compared to the $\mathrm{Ni}-\mathrm{N} 2$ and NiN3 distances of 3.83 and $3.48 \AA$ for the $\mathrm{N}$ atoms of the rings in the boat conformer of the $\mathrm{Ni}(0)$ complex, $\mathrm{Ni}\left(\mathrm{P}^{\mathrm{Cy}}{ }_{2} \mathrm{~N}^{t-\mathrm{Bu}}{ }_{2}\right)_{2}$. This is consistent with shortening of the $\mathrm{Ni}-\mathrm{N}$ distance due to the presence of a $\mathrm{Ni}^{0} \cdots \mathrm{H}-\mathrm{N}$ hydrogen bond. NMR studies on intramolecular proton exchange for isomer $\mathbf{B}$ of the complex $\left[\mathrm{Ni}\left(\mathrm{P}^{\mathrm{Cy}}{ }_{2} \mathrm{~N}_{2}^{\mathrm{Bn}}\right)_{2}\right]^{2+}$ indicates facile proton movement from an endo position on one $\mathrm{N}$ atom of the endo $\mathrm{P}_{2} \mathrm{~N}_{2}$ ligand to the other $\mathrm{N}$ atom, via a $\mathrm{NiH}$ intermediate. ${ }^{64}$ This is also observed in the singly protonated complex $\left[\mathrm{Ni}(\mathrm{dppp})\left(\mathrm{P}^{\mathrm{Ph}}{ }_{2} \mathrm{~N}^{\mathrm{Bn}}{ }_{2} \mathrm{H}\right)\right]^{+}$, where the endoproton undergoes rapid exchange $\left(10^{4} \mathrm{~s}^{-1}\right.$ at 10 ${ }^{\circ} \mathrm{C}$ ) between the two amines through a $\mathrm{NiH}$ intermediate. ${ }^{48}$

The $\mathrm{Ni}^{\mathrm{II}}$ complex $\left[\mathrm{Ni}\left(\mathrm{P}^{\mathrm{Cy}}{ }_{2} \mathrm{~N}^{t-\mathrm{Bu}}{ }_{2}\right)_{2}\right]^{2+}$ reacts with hydrogen to produce a doubly protonated $\mathrm{Ni}^{0}$ complex. The kinetic product of addition of $\mathrm{H}_{2}$ to $\left[\mathrm{Ni}\left(\mathrm{P}^{\mathrm{Cy}}{ }_{2} \mathrm{~N}^{t-\mathrm{Bu}}{ }_{2}\right)_{2}\right]^{2+}$ in the absence of water is isomer $\mathbf{A}$, which has both protons endo with respect to the metal. This isomer rearranges through intermolecular proton transfers over several hours to form isomers $\mathbf{B}$ and $\mathbf{C}$, which is similar to the behavior observed for the related complex $\left[\mathrm{Ni}\left(\mathrm{P}^{\mathrm{Cy}}{ }_{2} \mathrm{~N}_{2}^{\mathrm{Bn}}\right)_{2}\right]^{2+}$ upon reaction with hydrogen. ${ }^{64,80}$ Addition of water facilitates this intermolecular exchange, resulting in a more rapid approach to equilibrium, which is achieved in approximately five hours. The observed equilibrium indicates that these species are nearly of equal energy (within $1.3 \mathrm{kcal} /$ $\mathrm{mol}$ of each other at room temperature). The driving force for $\mathrm{H}_{2}$ addition to complex $\left[\mathrm{Ni}\left(\mathrm{P}^{\mathrm{Cy}}{ }_{2} \mathrm{~N}^{t-\mathrm{Bu}}{ }_{2}\right)_{2}\right]^{2+}$ is determined by the hydride and proton acceptor abilities of this complex as shown in Scheme 4. The hydride acceptor ability $\left(-\Delta G_{\mathrm{H}^{-}}^{\circ}\right)$ was experimentally determined from the $\mathrm{p} K_{\mathrm{a}}$ value of $\left[\mathrm{HNi}\left(\mathrm{P}^{\mathrm{Cy}}{ }_{2} \mathrm{~N}^{t-\mathrm{Bu}}{ }_{2}\right)_{2}\right]^{+}$and the $\mathrm{Ni}^{\mathrm{iI} / \mathrm{I}}$ and $\mathrm{Ni}^{\mathrm{i} / 0}$ potentials of $\left[\mathrm{Ni}\left(\mathrm{P}^{\mathrm{Cy}}{ }_{2} \mathrm{~N}^{t-\mathrm{Bu}}\right)_{2}\right]_{2}^{2+}$ to be $-61.3 \mathrm{kcal} / \mathrm{mol}$, very close to the $-60.7 \mathrm{kcal} / \mathrm{mol}$ measured for $\left[\mathrm{Ni}\left(\mathrm{P}_{2}^{\mathrm{Cy}} \mathrm{N}_{2}{ }_{2}\right)_{2}\right]^{2+}$. . However, replacing the benzyl substituent on the pendant amine with a $t$ - butyl group increases the $\mathrm{p} K_{\mathrm{a}}$ from 13.4 to 16.5 . This corresponds to a more negative free energy $\left(\Delta G_{\mathrm{H}_{2}}^{\circ}\right)$ for addition of $\mathrm{H}_{2}$ to $\left[\mathrm{Ni}\left(\mathrm{P}^{\mathrm{Cy}}{ }_{2} \mathrm{~N}^{t-\mathrm{Bu}}{ }_{2}\right)_{2}\right]\left(\mathrm{BF}_{4}\right)_{2}$, from -3.1 to -7.9 $\mathrm{kcal} / \mathrm{mol}$. Thus replacing the benzyl substituent on the pendant amine with a $t$-Bu substituent increases the driving force for $\mathrm{H}_{2}$ addition by $4.8 \mathrm{kcal} / \mathrm{mol}$, more than the $1.8 \mathrm{kcal} / \mathrm{mol}$ difference expected on the basis of the $\mathrm{p} K_{\mathrm{a}}$ values of protonated benzylamine (16.8) and protonated $t$-butylamine (18.1) in acetonitrile. This correlates with an increase in catalytic rate, as shown in Table 3.

The cyclic voltammograms of the three nearly isoenergetic isomers $\mathbf{A}, \mathbf{B}$, and $\mathbf{C}$ show different oxidation potentials, as shown in Figure 3. Each of these isomers has two hydrogen bonds. For isomer $\mathbf{C}$ there are two $\mathrm{N} \cdots \mathrm{H}-\mathrm{N}$ hydrogen bonds, for isomer $\mathbf{B}$ there is one $\mathrm{N} \cdots \mathrm{H}-\mathrm{N}$ hydrogen bond and one $\mathrm{Ni} \cdots \mathrm{H}-\mathrm{N}$ hydrogen bond, and for isomer $\mathbf{A}$ there are two $\mathrm{Ni} \cdots \mathrm{H}-\mathrm{N}$ hydrogen bonds. Theoretical calculations on $[\mathrm{Ni}-$ $\left.\left(\mathrm{P}^{\mathrm{Cy}}{ }_{2} \mathrm{HN}^{\mathrm{Bn}}\right)_{2}\right]^{2+}$ indicate that the $\mathrm{N} \cdots \mathrm{H}-\mathrm{N}$ hydrogen bonds and the $\mathrm{Ni} \cdots \mathrm{H}-\mathrm{N}$ hydrogen bonds are of roughly equal energy. ${ }^{73}$ Isomer $\mathbf{C}$ is the easiest to oxidize (most negative redox potential), followed by isomers $\mathbf{B}$ and $\mathbf{A}$. The dramatic differences in oxidation potentials for these three conformers are due to the presence of hydrogen bonds between the $\mathrm{Ni}$ and the endo proton of the pendant amine. The $\mathrm{Ni} \cdots \mathrm{H}-\mathrm{N}$ hydrogen bond stabilizes the $\mathrm{HOMO}$ of the $\mathrm{Ni}^{0}$, which results in a higher oxidation potential for the metal. For isomer $\mathbf{A}$, two $\mathrm{Ni} \cdots \mathrm{H}-\mathrm{N}$ hydrogen bonds are broken upon oxidation of $\mathrm{Ni}^{0}$ to $\mathrm{Ni}^{\mathrm{I}}$. For isomer $\mathbf{B}$, one $\mathrm{Ni} \cdots \mathrm{H}-\mathrm{N}$ bond is broken upon oxidation to $\mathrm{Ni}(\mathrm{I})$, and for isomer $\mathrm{C}$, no $\mathrm{Ni} \cdots \mathrm{H}-\mathrm{N}$ hydrogen bonds are broken upon oxidation. As a result, the relative stability of the oxidized isomers is expected to be $\mathrm{C}^{+}$(with two $\mathrm{N} \cdots \mathrm{H}-\mathrm{N}$ bonds) $>\mathbf{B}^{+}$(with one $\mathrm{N} \cdots \mathrm{H}-\mathrm{N}$ bond) $>\mathbf{A}^{+}$(with no $\mathrm{N} \cdots \mathrm{H}-\mathrm{N}$ bonds). Other examples of hydrogen bonds with transition metals have been reported, with bond enthalpies estimated to be between 3 and $7 \mathrm{kcal} / \mathrm{mol}^{81-85}$ Similar trends in electrochemical data have also been observed experimentally in the analogous complex $\left[\mathrm{Ni}\left(\mathrm{P}^{t-\mathrm{Bu}}{ }_{2} \mathrm{~N}^{\mathrm{Bn}}{ }_{2} \mathrm{H}\right)_{2}\right]^{2+} .^{73}$ The magnitude of the oxidation potential differences in that complex was consistent with DFT calculations of the free energies of each of the species. ${ }^{73}$ The difference in the oxidation potential between isomer $\mathbf{B}$ and $\mathbf{C}$ is $410 \mathrm{mV}$, which corresponds to an energy of $9.4 \mathrm{kcal} / \mathrm{mol}$ for the $\mathrm{Ni} \cdots \mathrm{H}-\mathrm{N}$ bond in isomer $\mathbf{B}$. The oxidation potential for isomer $\mathbf{A}$ is 530 $\mathrm{mV}$ more positive than that for isomer $\mathbf{C}$, suggesting that the two $\mathrm{Ni} \cdots \mathrm{H}-\mathrm{N}$ hydrogen bonds in isomer $\mathbf{A}$ are worth 12.2 $\mathrm{kcal} / \mathrm{mol}$. The difference in oxidation potentials resulting from the $\mathrm{Ni} \cdots \mathrm{H}-\mathrm{N}$ hydrogen bonds may have implications for the operating potential (and overpotentials) of these catalysts.

During the catalytic cycle (Scheme 5) the kinetic product of $\mathrm{H}_{2}$ addition to $\left[\mathrm{Ni}\left(\mathrm{P}^{\mathrm{Cy}}{ }_{2} \mathrm{~N}^{t-\mathrm{Bu}}{ }_{2}\right)_{2}\right]^{2+}$ is isomer A. Oxidation of isomer $\mathrm{A}$ at $-0.36 \mathrm{~V}$ will lead to cleavage or weakening of the $\mathrm{Ni} \cdots \mathrm{H}-\mathrm{N}$ bond, facilitating the boat to chair conformational change that may be required for the intermolecular transfer of a proton to the bulky $\mathrm{NEt}_{3}$ base in solution. In addition, the proton on the pendant amine will be much more acidic after oxidation of $\mathrm{Ni}^{0}$ to $\mathrm{Ni}^{\mathrm{I}}$. Because the proton on the pendant base is more sterically accessible and more acidic, $\mathrm{NEt}_{3}$ can readily deprotonate this doubly protonated $\mathrm{Ni}^{\mathrm{I}}$ species in two sequential steps to form the unprotonated $\mathrm{Ni}^{\mathrm{I}}$ species, which is rapidly oxidized to regenerate $\left[\mathrm{Ni}\left(\mathrm{P}^{\mathrm{Cy}}{ }_{2} \mathrm{~N}^{t-B u}{ }_{2}\right)_{2}\right]^{2+}$. Thus the catalytic wave observed in the presence of $\mathrm{NEt}_{3}$ at $-0.36 \mathrm{~V}$ 
Scheme 5. Proposed Mechanism for Electrocatalytic Oxidation of $\mathbf{H}_{2}$, Showing That Deprotonation Followed by Oxidation Occurs at a More Negative Potential (Lower Overpotential) than Oxidation Followed by Proton Transfer ${ }^{a}$

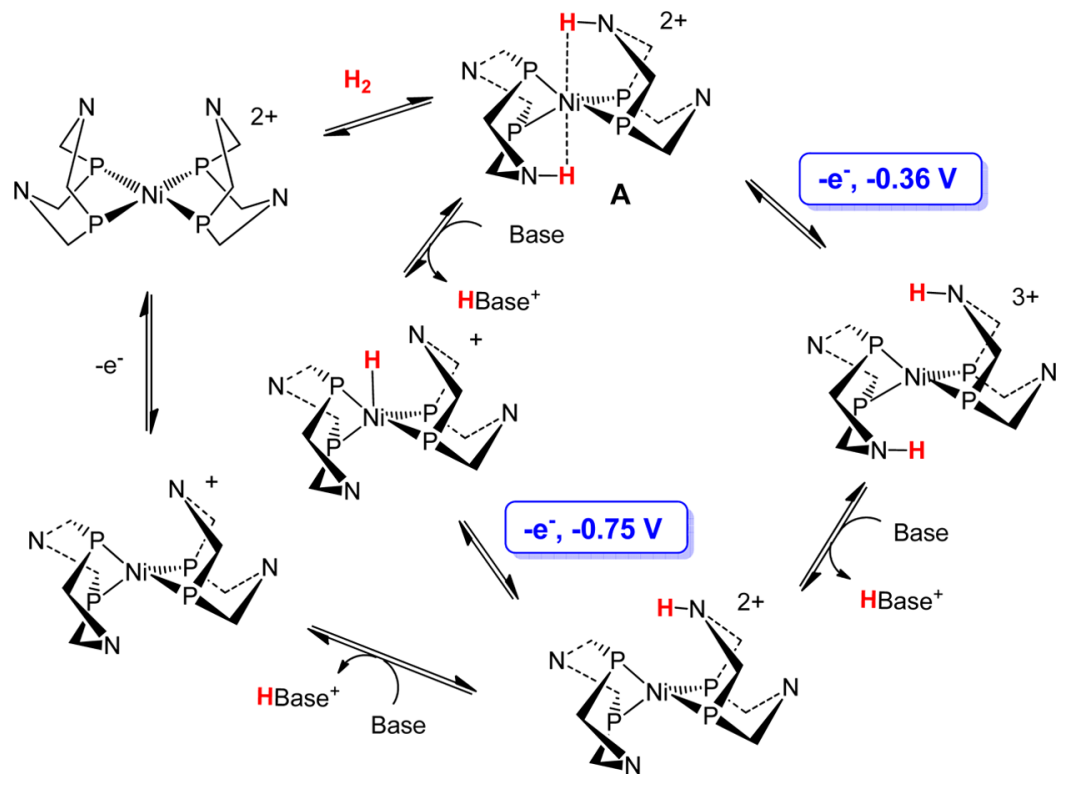

${ }^{a} \mathrm{R}$ groups on $\mathrm{P}$ and $\mathrm{R}^{\prime}$ groups on $\mathrm{N}$ not shown.

(Figure 4) results from oxidation of the doubly protonated $\mathrm{Ni}^{0}$ species, A, followed by proton transfer.

An alternate catalytic pathway observed in the presence of $\mathrm{NEt}_{3}$ involves the direct deprotonation of isomer $\mathbf{A}$. This deprotonation reaction will lead to the formation of the nickel hydride complex, as shown in Scheme 5. Subsequent oxidation of $\left[\mathrm{HNi}\left(\mathrm{P}^{\mathrm{Cy}}{ }_{2} \mathrm{~N}^{t-\mathrm{Bu}}{ }_{2}\right)_{2}\right]^{+}$would likely occur at potentials positive of the $\mathrm{Ni}^{\mathrm{II} / \mathrm{I}}$ couple, but rapid proton transfer from this oxidized hydride species will shift this potential in a negative direction such that it can approach the potential of the $\mathrm{Ni}(\mathrm{II} / \mathrm{I})$ couple, as observed, leading to the catalytic wave observed at approximately $-0.75 \mathrm{~V}$ in Figure 4 . Thus in the presence of $\mathrm{NEt}_{3}$ in "dry" solvent, two competing pathways for catalysis are observed, and they occur at different potentials. For the catalytic wave observed at $-0.75 \mathrm{~V}$, deprotonation of $\mathbf{A}$ is followed by oxidation (Scheme 5). In the catalytic wave observed at $-0.36 \mathrm{~V}$, oxidation of $\mathbf{A}$ occurs before deprotonation. The $0.38 \mathrm{~V}$ more positive oxidation potential for the wave at $-0.36 \mathrm{~V}$ results in a corresponding increase of that magnitude in the overpotential for hydrogen oxidation. These results clearly indicate the importance of the sequence and pathway for proton movement in determining overpotentials,

An increase in catalytic current is observed at $-0.75 \mathrm{~V}$ upon addition of water, as shown in Figure 4. Water facilitates the deprotonation of the hydrogen addition product by making the endo proton more accessible. The use of sterically hindered amines $\left(\mathrm{NEt}_{3}\right.$ and $t$ - $\left.\mathrm{BuNH}_{2}\right)$ as the base results in slow catalysis in the absence of water, which increases by an order of magnitude upon addition of water. However, the use of the smaller base $n$-butylamine gives fast catalysis in the absence of water, and only a slight increase with addition of water (see Figure 5). Therefore, it appears that in the absence of water, deprotonation and subsequent catalysis at the lower overpotential is hindered by steric interference, and this effect is overcome by the presence of water.

We propose two possible avenues for the acceleration by water (Scheme 6). One possibility is that water forms a hydrogen bond with the endo proton, weakening the $\mathrm{Ni} \cdots \mathrm{H}-\mathrm{N}$ hydrogen bond (Scheme 6a). This would stabilize a boat-tochair conformational change of the six-membered ring containing the endo proton, creating easier access for deprotonation by the base. A similar boat-to-chair conformational change is required for the intermolecular proton transfer required to isomerize $\mathbf{A}$ to $\mathbf{B}$ or $\mathbf{C}$, and our NMR spectroscopic and theoretical studies have established that water facilitates that isomerization. ${ }^{80}$ Alternatively, water may form a hydrogen bond network that allows deprotonation of a distal, more accessible proton from water, which deprotonates the $\mathrm{N}-\mathrm{H}$, thus relieving the steric requirements for deprotonation (Scheme 6b). At this time, we are unable to distinguish whether one effect is dominant, or if it is a combination of both, but we are continuing experimental and theoretical studies to determine the contributions for the influence of water on the catalytic rate.

In the presence of excess $\mathrm{NEt}_{3}$ and water, or in the presence of excess $n-\mathrm{BuNH}_{2}$, the catalytic rate is independent of the concentration of base, and the observed catalytic potential is near that of the $\mathrm{Ni}^{\mathrm{II} / \mathrm{I}}$ couple of $\left[\mathrm{Ni}\left(\mathrm{P}^{\mathrm{Cy}}{ }_{2} \mathrm{~N}^{t-\mathrm{Bu}}{ }_{2}\right)_{2}\right]^{2+}$. These data suggest that under these conditions, the catalytic rate for $\mathrm{H}_{2}$ oxidation does not depend on the rate of intermolecular proton transfer, suggesting that $\mathrm{H}_{2}$ addition may be the rate-limiting step. In this case an increase in the driving force for $\mathrm{H}_{2}$ addition is expected to result in faster catalysis. Indeed, the TOF for $\left[\mathrm{Ni}\left(\mathrm{P}^{\mathrm{Cy}}{ }_{2} \mathrm{~N}^{t-\mathrm{Bu}}{ }_{2}\right)_{2}\right]^{2+}$ (with a driving force for $\mathrm{H}_{2}$ addition of $-7.9 \mathrm{kcal} / \mathrm{mol}$ ) under $1.0 \mathrm{~atm}$ of $\mathrm{H}_{2}$ of $45 \mathrm{~s}^{-1}$ is significantly faster than the TOF of $10 \mathrm{~s}^{-1}$ reported previously for $\left[\mathrm{Ni}\left(\mathrm{P}^{\mathrm{Cy}}{ }_{2} \mathrm{~N}_{2}^{\mathrm{Bn}}\right)_{2}\right]^{2+}$ (with a driving force of $-3.1 \mathrm{kcal} / \mathrm{mol}$ ).

\section{CONCLUSIONS}

$\left[\mathrm{Ni}\left(\mathrm{P}^{\mathrm{Cy}}{ }_{2} \mathrm{~N}^{t-\mathrm{Bu}}\right)_{2}\right]^{2+}$ is the fastest reported molecular catalyst reported for hydrogen oxidation, an essential reaction for the conversion of chemical energy to electrical energy in hydrogen fuel cells. $\left[\mathrm{Ni}\left(\mathrm{P}_{2}^{\mathrm{Cy}}{ }_{2} \mathrm{~N}^{t-\mathrm{Bu}}{ }_{2}\right)_{2}\right]^{2+}$ binds hydrogen preferentially over $\mathrm{CO}$, a common impurity in hydrogen produced from 


\section{Scheme 6. Two Possible Mechanisms for Acceleration by Water}

(a)

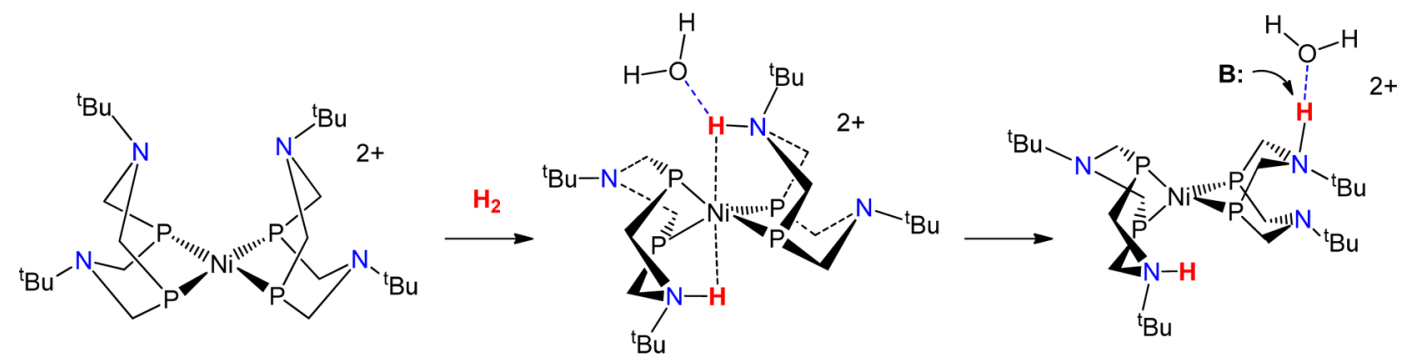

(b)

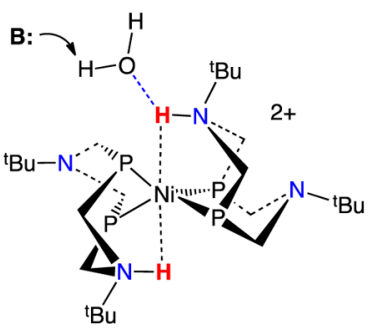

steam reforming of methane, which poisons platinum, the catalyst used in most low-temperature hydrogen fuel cells. The fast rate of the Ni catalyst reported here is attributed to the high driving force for heterolytic cleavage of hydrogen. Two of the products of hydrogen addition have been characterized by Xray crystallography, providing confirmation of the structure proposed on the basis of NMR studies.

The rate of hydrogen oxidation catalysis is accelerated by the addition of water. Our NMR and electrochemical studies demonstrated that water is important for fast intermolecular proton transfer. The kinetic product of hydrogen addition has the protons on the pendant amines in an endo position facing the metal. In this position, the protons are stabilized by a $\mathrm{Ni} \cdots \mathrm{H}-\mathrm{N}$ hydrogen bond that decreases the electron density of the metal, resulting in a more positive oxidation potential. Cleavage of the $\mathrm{Ni} \cdots \mathrm{H}-\mathrm{N}$ hydrogen bond and removal of the proton from the second coordination sphere is one observed pathway for catalysis. This pathway is facilitated by water or small bases such as $n$-butylamine. An alternative catalytic pathway involves the oxidation of the doubly protonated $\mathrm{Ni}^{0}$ complex prior to deprotonation. This pathway requires a more positive oxidation potential, which results in an increase in the overpotential. With large external bases, water is critical for fast proton removal and therefore fast catalytic rates as well as operating at a more modest potential. These results provide valuable insight into the different catalytic cycles possible for hydrogen oxidation and the importance of the sequence of proton and electron transfer steps for fast catalysis and low overpotentials.

\section{EXPERIMENTAL SECTION}

General Experimental Procedures. ${ }^{1} \mathrm{H}$, and ${ }^{31} \mathrm{P}\left\{{ }^{1} \mathrm{H}\right\}$ NMR spectra were recorded on a Varian Inova spectrometer $(500 \mathrm{MHz}$ for ${ }^{1} \mathrm{H}$ ) at $20{ }^{\circ} \mathrm{C}$ unless otherwise noted. All ${ }^{1} \mathrm{H}$ chemical shifts have been internally calibrated to the monoprotio impurity of the deuterated solvent. The ${ }^{31} \mathrm{P}$ NMR spectra were proton decoupled and referenced to external phosphoric acid.
All electrochemical experiments were carried out under an atmosphere of nitrogen, or hydrogen when indicated, in $0.2 \mathrm{M}$ $\mathrm{Bu}_{4} \mathrm{NBF}_{4}$ acetonitrile solutions. Cyclic voltammetry experiments were performed with a $\mathrm{CH}$ Instruments model $660 \mathrm{C}$ potentiostat. Ferrocene was used as an internal standard, and all potentials are referenced to the $\mathrm{Cp}_{2} \mathrm{Fe}^{+/ 0}$ couple. ${ }^{86,87}$

Synthesis and Materials. All reactions and manipulations were performed under an $\mathrm{N}_{2}$ atmosphere using standard Schlenk techniques or a glovebox unless otherwise indicated. Solvents were dried using an activated alumina column. Triethylamine was dried over $\mathrm{CaH}_{2}$ and vacuum transferred, while tert-butylamine and $n$-butylamine were dried over potassium hydroxide. $\mathrm{Bu}_{4} \mathrm{NBF}_{4}$ was dried at $100{ }^{\circ} \mathrm{C}$ under a vacuum for $12 \mathrm{~h}$. $\mathrm{P}^{\mathrm{Cy}}{ }_{2} \mathrm{~N}^{t-\mathrm{Bu}}$ and $\left[\mathrm{Ni}\left(\mathrm{P}^{\mathrm{Cy}}{ }_{2} \mathrm{~N}^{t-\mathrm{Bu}}{ }_{2}\right)_{2}\right]\left(\mathrm{BF}_{4}\right)_{2}$ was prepared using a literature method. ${ }^{50} \mathrm{Ni}(\mathrm{COD})_{2}$ was purchased from Strem Chemicals. The acid salt $[\mathrm{H}-\mathrm{DMAP}]^{+} \mathrm{BF}_{4}^{-}$was synthesized by reaction of the corresponding base with a stoichiometric amount of $\mathrm{HBF}_{4}$ in diethyl ether and isolated by filtration. ${ }^{88}[\mathrm{H}-\mathrm{MTBD}]^{+} \mathrm{BPh}_{4}{ }^{-},[\mathrm{H}-$ $\mathrm{DBU}]^{+} \mathrm{BPh}_{4}{ }^{-}$were synthesized by adding a stoichiometric amount of aqueous $\mathrm{HCl}$ to the amine in methanol, followed by a stoichiometric amount of $\mathrm{NaBPh}_{4}$, as previously described. ${ }^{89}$ The dihydrogen used in the synthesis was UHP grade and passed through a hydrogen purification column purchased from Vici Metronics.

Preparation of $\left[\mathrm{Ni}\left(\mathrm{P}^{\mathrm{Cy}}{ }_{2} \mathrm{~N}^{t-\mathrm{Bu}}{ }_{2}\right)_{2}\right]$. A solution of the ligand $\mathrm{P}^{\mathrm{Cy}}{ }_{2} \mathrm{~N}^{t-\mathrm{Bu}}$ $(0.500 \mathrm{~g}, 1.17 \mathrm{mmol})$ in $6 \mathrm{~mL}$ of tetrahydrofuran was cooled in a dry ice/isopropanol bath $\left(-40^{\circ} \mathrm{C}\right) . \mathrm{Ni}(\mathrm{COD})_{2}$ was added $(0.161 \mathrm{~g}, 0.587$ $\mathrm{mmol}$ ), and the solution was warmed to room temperature over an hour. The solvent was then removed under reduced pressure, and the remaining pale yellow solid was washed with acetonitrile and dried under a vacuum $(0.440 \mathrm{~g}, 82 \%$ yield $) .{ }^{1} \mathrm{H}$ and ${ }^{31} \mathrm{P}\left\{{ }^{1} \mathrm{H}\right\}$ NMR spectra were consistent with the previously reported complex. ${ }^{50}$

$\left[\mathrm{Ni}\left(\mathrm{P}^{\mathrm{Cy}}{ }_{2} \mathrm{~N}^{t-\mathrm{Bu}}{ }_{2}\right)_{2}\right]\left(\mathrm{BF}_{4}\right) . \quad\left[\mathrm{Ni}\left(\mathrm{P}^{\mathrm{Cy}}{ }_{2} \mathrm{~N}^{t-\mathrm{Bu}}{ }_{2}\right)_{2}\right]\left(\mathrm{BF}_{4}\right)_{2} \quad(25 \mathrm{mg}, 0.027$ $\mathrm{mmol})$ and $\left[\mathrm{Ni}\left(\mathrm{P}^{\mathrm{Cy}}{ }_{2} \mathrm{~N}^{t-\mathrm{Bu}}{ }_{2}\right)_{2}\right](20 \mathrm{mg}, 0.027 \mathrm{mmol})$ was added to 3 $\mathrm{mL}$ of acetonitrile, and the resulting solution was stirred at room temperature for $1 \mathrm{~h}$. The solvent was removed under reduced pressure to give the product as an orange solid ( $45 \mathrm{mg}, 100 \%$ yield). The solution magnetic susceptibility in $\mathrm{CD}_{3} \mathrm{CN}$ was determined by the Evans method to be $1.90 \mu_{\mathrm{B}} \cdot{ }^{61-63}$ The diamagnetic correction for $\left[\mathrm{Ni}^{\mathrm{I}}\left(\mathrm{P}^{\mathrm{C}}{ }_{2} \mathrm{~N}^{t-\mathrm{Bu}}\right)_{2}\right]\left(\mathrm{BF}_{4}\right)$ was estimated using Pascal's constants. Anal. Calcd for $\mathrm{C}_{48} \mathrm{H}_{96} \mathrm{BF}_{4} \mathrm{~N}_{4} \mathrm{NiP}_{4}$ : C, 57.73; H, 9.69; N, 5.61. Found: C, 57.58; H, 9.75; N, 5.51.

$\mathrm{p} K_{\mathrm{a}}$ Determination of $\left[\mathrm{HNi}\left(\mathrm{P}^{\mathrm{Cy}}{ }_{2} \mathrm{~N}^{t-\mathrm{Bu}_{2}}\right)_{2}\right]\left(\mathrm{BF}_{4}\right)$. A saturated solution of $\left[\mathrm{Ni}\left(\mathrm{P}^{\mathrm{Cy}}{ }_{2} \mathrm{~N}^{t-\mathrm{Bu}}{ }_{2}\right)_{2}\right]$ in benzonitrile $(500 \mu \mathrm{L}, 0.4 \mathrm{mM}, 0.2$ 
$\mu \mathrm{mol}$ ) was added to an NMR tube followed by $100 \mu \mathrm{L}$ of a buffered solution of MTBD: [H-MTBD] ${ }^{+} \mathrm{BPh}_{4}{ }^{-}$(44.4 mM MTBD: $41.9 \mathrm{mM}$ $[\mathrm{H}-\mathrm{MTBD}]^{+} \mathrm{BPh}_{4}{ }^{-} ; 4.44 \mu \mathrm{mol} \mathrm{MTBD}$ and $4.19 \mu \mathrm{mol}[\mathrm{H}-$ MTBD $]^{+} \mathrm{BPh}_{4}{ }^{-}$). The sample was analyzed by ${ }^{31} \mathrm{P}\left\{{ }^{1} \mathrm{H}\right\}$ NMR spectroscopy at $25{ }^{\circ} \mathrm{C}$ using a delay time of $6 \mathrm{~s}$ and an acquisition time of $4 \mathrm{~s}$ to determine the concentration of $\left[\mathrm{Ni}\left(\mathrm{P}^{\mathrm{Cy}}{ }_{2} \mathrm{~N}^{t-\mathrm{Bu}}{ }_{2}\right)_{2}\right]$ and $\left[\mathrm{HNi}\left(\mathrm{P}^{\mathrm{Cy}}{ }_{2} \mathrm{~N}^{t-\mathrm{Bu}}{ }_{2}\right)_{2}\right]\left(\mathrm{BF}_{4}\right)$. The NMR data were acquired over a period of $14 \mathrm{~h}$. This procedure was repeated once more using a different ratio of MTBD: [H-MTBD] ${ }^{+} \mathrm{BPh}_{4}{ }^{-}(4.44 \mu \mathrm{mol} \mathrm{MTBD}, 7.08 \mu \mathrm{mol}[\mathrm{H}-$ $\left.\mathrm{MTBD}]^{+} \mathrm{BPh}_{4}^{-}\right)$. An equilibrium constant of $K_{\text {eq }}=9( \pm 6)$ was determined. The use of this $K_{\text {eq }}$ value in combination with the known $\mathrm{p} K_{\mathrm{a}}$ value of MTBD in acetonitrile (25.49) was used to determine the $\mathrm{p} K_{\mathrm{a}}$ of the $\mathrm{Ni}-\mathrm{H}$ complex of $24.6( \pm 0.3)$. Additionally, the $\mathrm{p} K_{\mathrm{a}}$ for the $\mathrm{Ni}-\mathrm{H}$ complex was determined using the same procedure as above, but with a different base and conjugate acid, $\mathrm{DBU}$ : $[\mathrm{H}-\mathrm{DBU}]^{+} \mathrm{BPh}_{4}{ }^{-}$ (4.2 $\mu \mathrm{mol}$ DBU: $4.51 \mu \mathrm{mol}[\mathrm{H}-\mathrm{DBU}]^{+} \mathrm{BPh}_{4}{ }^{-}$). The equilibrium constant for this reaction is $K_{\mathrm{eq}}=0.41$, yielding a $\mathrm{p} K_{\mathrm{a}}$ for $\left[\mathrm{HNi}\left(\mathrm{P}^{\mathrm{Cy}}{ }_{2} \mathrm{~N}^{t-\mathrm{Bu}}{ }_{2}\right)_{2}\right]^{+}$of 24.7 when the $\mathrm{pK}$ a value of $24.34^{67}$ for [H$\mathrm{DBU}]^{+}$in acetonitrile is used.

$\mathrm{p} K_{\mathrm{a}}$ Determination of $\left[\mathrm{Ni}\left(\mathrm{P}^{\mathrm{Cy}}{ }_{2} \mathrm{~N}^{\mathrm{t}-\mathrm{Bu}}{ }_{2} \mathrm{H}\right)_{2}\right]\left(\mathrm{BF}_{4}\right)_{2}$. A solution of $\left[\mathrm{Ni}\left(\mathrm{P}^{\mathrm{Cy}}{ }_{2} \mathrm{~N}^{t-\mathrm{Bu}}\right)_{2}\right]\left(\mathrm{BF}_{4}\right)_{2}(600 \mu \mathrm{L}, 9.75 \mathrm{mM}, 5.85 \mu \mathrm{mol})$ and DMAP $(20 \mu \mathrm{L}, 94.9 \mathrm{mM}, 1.90 \mu \mathrm{mol})$ in $\mathrm{CD}_{3} \mathrm{CN}$ was added to an NMR tube via a syringe. Hydrogen was sparged through the solution for $5 \mathrm{~min}$, resulting in a color change from red-orange to pale yellow. The sample was analyzed by both ${ }^{1} \mathrm{H}$ and ${ }^{31} \mathrm{P}\left\{{ }^{1} \mathrm{H}\right\}$ NMR spectroscopy at $25^{\circ} \mathrm{C}$ to determine the concentration of DMAP and $[\mathrm{H}-\mathrm{DMAP}]^{+} \mathrm{BF}_{4}{ }^{-}$from the ${ }^{1} \mathrm{H}$ NMR spectrum and to determine the concentration of the isomers of $\left[\mathrm{Ni}\left(\mathrm{P}_{2}{ }_{2} \mathrm{~N}^{t-B u}{ }_{2} \mathrm{H}\right)_{2}\right]\left(\mathrm{BF}_{4}\right)_{2}$ and $\left[\mathrm{HNi}\left(\mathrm{P}^{\mathrm{Cy}}{ }_{2} \mathrm{~N}^{\mathrm{t}-\mathrm{Bu}}{ }_{2}\right)_{2}\right]\left(\mathrm{BF}_{4}\right)$. The chemical exchange of DMAP and [H-DMAP $]^{+} \mathrm{BF}_{4}{ }^{-}$is fast on the NMR time scale, and the weighted average was used to determine the relative concentrations of DMAP and $[\mathrm{H}-\mathrm{DMAP}]^{+} \mathrm{BF}_{4}^{-}$. Proton transfer exchange of the nickel species is slow on the NMR time scale, and integration of the peaks determined the relative concentrations of these compounds. The ${ }^{31} \mathrm{P}\left\{{ }^{1} \mathrm{H}\right\}$ spectrum was acquired at $25{ }^{\circ} \mathrm{C}$ using a delay time of $11 \mathrm{~s}$ and an acquisition time of $4 \mathrm{~s}$ to determine the concentration of the isomers of $[\mathrm{Ni}$ $\left.\left(\mathrm{P}^{\mathrm{Cy}}{ }_{2} \mathrm{~N}^{t-\mathrm{Bu}}{ }_{2} \mathrm{H}\right)_{2}\right]\left(\mathrm{BF}_{4}\right)_{2}$ and $\left[\mathrm{HNi}\left(\mathrm{P}^{\mathrm{Cy}}{ }_{2} \mathrm{~N}^{t-\mathrm{Bu}}{ }_{2}\right)_{2}\right]\left(\mathrm{BF}_{4}\right)$. This procedure was repeated two more times by adding additional aliquots of DMAP corresponding to 2.8 and 3.8 additional $\mu$ mol. The equilibrium constant for the isomers of this reaction are $K_{\mathrm{A} \text { eq }}=240( \pm 20), K_{\mathrm{B} \text { eq }}=$ $70( \pm 10)$ and $K_{\text {Ceq }}=31( \pm 6)$. The use of these $K_{\text {eq }}$ values in combination with the known $\mathrm{p} K_{\mathrm{a}}$ value of DMAP in acetonitrile (17.95) was used to determine the $\mathrm{p} K_{\mathrm{a}}$ of the isomers $\mathbf{A}, \mathbf{B}$, and $\mathbf{C}$ of 15.6, 16.1, and 16.5. The $\mathrm{pK}$ of $\left[\mathrm{Ni}\left(\mathrm{P}^{\mathrm{Cy}}{ }_{2} \mathrm{~N}^{t-\mathrm{Bu}}{ }_{2} \mathrm{H}\right)_{2}\right]\left(\mathrm{BF}_{4}\right)_{2}$ was further determined by adding $\left[\mathrm{Ni}\left(\mathrm{P}_{2}^{\mathrm{Cy}}{ }_{2} \mathrm{~N}^{t-\mathrm{Bu}}\right)_{2}\right)_{2}(11.4 \mathrm{mg}, 12.5 \mu \mathrm{mol})$ to an NMR tube and adding a solution of $\mathrm{CD}_{3} \mathrm{CN}$ (ca. $0.6 \mathrm{~mL}$ ) containing 2,6-lutidinium ( $4.2 \mathrm{mg}, 22 \mu \mathrm{mol}$ ). The solution was then sparged with $\mathrm{H}_{2}$ for 5 min. Analysis of both the ${ }^{1} \mathrm{H}$ and ${ }^{31} \mathrm{P}\left\{{ }^{1} \mathrm{H}\right\}$ NMR using the above procedure yielded equilibrium constants of $K_{2 \mathrm{~A} / \mathrm{eq}}=0.077, K_{2 \mathrm{~B}}$ eq $=0.028$, and $K_{2 \mathrm{C} \text { eq }}=0.0093$, yielding $\mathrm{p} K_{\mathrm{a}}$ values of $15.2,15.7$, and 16.2 for the $\left[\mathrm{Ni}\left(\mathrm{P}^{\mathrm{Cy}}{ }_{2} \mathrm{~N}^{t-\mathrm{Bu}}{ }_{2} \mathrm{H}\right)_{2}\right]\left(\mathrm{BF}_{4}\right)_{2}$ isomers when a $\mathrm{pK} K_{\mathrm{a}}$ value of 14.13 in acetonitrile is used for 2,6-lutidinium. ${ }^{89}$

Population of Isomers $A, B$, and $C$ upon Hydrogen Addition to $\left[\mathrm{Ni}\left(\mathrm{P}^{\mathrm{Cy}}{ }_{2} \mathrm{~N}^{t-\mathrm{Bu}}{ }_{2}\right)_{2}\right]\left(\mathrm{BF}_{4)}\right]_{2}$. Twenty milligrams $(18.4 \mu \mathrm{mol})$ of $\left[\mathrm{Ni}\left(\mathrm{P}^{\mathrm{Cy}}{ }_{2} \mathrm{~N}^{t-\mathrm{Bu}}{ }_{2}\right)_{2}\right]\left(\mathrm{BF}_{4}\right)_{2}$ was added to $0.8 \mathrm{~mL}$ of $\mathrm{CD}_{3} \mathrm{CN}$ in an NMR tube. The solution was sparged with hydrogen for $5 \mathrm{~min}$. A ${ }^{31} \mathrm{P}\left\{{ }^{1} \mathrm{H}\right\}$ NMR spectrum was taken every $20 \mathrm{~min}$ for $13 \mathrm{~h}$. The ratio of isomers $\mathbf{A}, \mathbf{B}$, and $\mathbf{C}$ was determined by integration. To obtain the isomer populations in the presence of water, the same experiment was performed, except $3.3 \mu \mathrm{L}$ of $\mathrm{H}_{2} \mathrm{O}(184 \mu \mathrm{mol}, 0.22 \mathrm{M})$ was added to the solution.

Reaction of $\left[\mathrm{Ni}\left(\mathrm{P}^{\mathrm{Cy}}{ }_{2} \mathrm{~N}^{t-\mathrm{Bu}}{ }_{2}\right)_{2}\right]\left(\mathrm{BF}_{4}\right)_{2}$ with Carbon Monoxide. Ten milligrams $(9.2 \mu \mathrm{mol})$ of $\left[\mathrm{Ni}\left(\mathrm{P}_{2}^{\mathrm{Cy}}{ }_{2} \mathrm{~N}^{t-\mathrm{Bu}}\right)_{2}\right]\left(\mathrm{BF}_{4}\right)_{2}$ was added to $1.0 \mathrm{~mL}$ of $\mathrm{CD}_{3} \mathrm{CN}$ in an NMR tube. The solution was sparged under 1 atm of $\mathrm{CO}$ for $5 \mathrm{~min}$, and the color changed from red to orange. The ${ }^{31} \mathrm{P}\left\{{ }^{1} \mathrm{H}\right\}$ NMR spectra displayed resonances at -43 and $15 \mathrm{ppm}$. No other resonances were observed. The solution was then sparged under an atmosphere of $\mathrm{H}_{2}$ for $5 \mathrm{~min}$. The ${ }^{31} \mathrm{P}\left\{{ }^{1} \mathrm{H}\right\}$ NMR spectrum displayed a resonance at $18.3 \mathrm{ppm}$, consistent with isomer A. Purging this solution with a $1: 1$ mixture of $\mathrm{CO}: \mathrm{H}_{2}$ resulted in no change to the ${ }^{31} \mathrm{P}\left\{{ }^{1} \mathrm{H}\right\}$ NMR spectra.

Cyclic Voltammograms of Isomers A, B, and C. $5.8 \mathrm{mg}(0.005$ $\mathrm{mmol})$ of $\left[\mathrm{Ni}\left(\mathrm{P}^{\mathrm{Cy}}{ }_{2} \mathrm{~N}^{t-\mathrm{Bu}}{ }_{2}\right)_{2}\right]\left(\mathrm{BF}_{4}\right)_{2}$ was dissolved in $3.0 \mathrm{~mL}$ of a $0.2 \mathrm{M}$ $\mathrm{Bu}_{4} \mathrm{NPF}_{6}$ solution of acetonitrile. A cyclic voltammogram was recorded, and the solution was then sparged with hydrogen for 5 min. The cyclic voltammgram of isomer $\mathbf{A}$ was then recorded. Ten equivalents of water $(0.050 \mathrm{mmol})$ were added, and another cyclic voltammogram was recorded after $8 \mathrm{~h}$ under an atmosphere of hydrogen.

Electrocatalytic Studies of $\left[\mathrm{Ni}\left(\mathrm{P}^{\mathrm{Cy}}{ }_{2} \mathrm{~N}^{t-\mathrm{Bu}}{ }_{2}\right)_{2}\right]\left(\mathrm{BF}_{4}\right)_{2}$. Studies were performed with three different amine bases and variable concentrations of water. In a typical procedure, a $0.5-1.0 \mathrm{mM}$ of $\left[\mathrm{Ni}\left(\mathrm{P}_{2}^{\mathrm{Cy}}{ }_{2} \mathrm{~N}^{t-\mathrm{Bu}}{ }_{2}\right)_{2}\right]\left(\mathrm{BF}_{4}\right)_{2}$ was prepared in $0.2 \mathrm{M} \mathrm{Bu}_{4} \mathrm{NPF}_{6}$ acetonitrile solution. $2.5 \mathrm{~mL}$ was used in each catalytic study. A cyclic voltammogram under nitrogen was recorded to measure $i_{\mathrm{p}}$. Hydrogen was then sparged through the solution for 5-10 min, and the cyclic voltammogram was again recorded. Aliquots of neat base were added $(1-10 \mu \mathrm{L})$, and the cyclic voltammogram recorded until there was no further increase in catalytic current. Water was then added in $1-20 \mu \mathrm{L}$ aliquots until there was no further increase in catalytic current. Plots of $i_{\text {cat }} / i_{\mathrm{p}}$ vs [base] for representative experiments with the different bases are shown in the Supporting Information.

X-ray Diffraction Studies. Crystals of compound $\mathbf{4}$ were removed from the flask, a suitable crystal was selected and attached to a glass fiber, and data were collected at 90(2) K using a Bruker/Siemens SMART APEX instrument (Mo $\mathrm{K} \alpha$ radiation, $\lambda=0.71073 \AA$ ) equipped with a Cryocool NeverIce low temperature device. The data for the two isomers (B and C) were collected at 90(2) K using Bruker KAPPA APEX II CCD diffractometer with $0.71073 \AA$ Mo K $\alpha$ radiation (see details in CIF files in the Supporting Information). Cell parameters were retrieved using SMART ${ }^{44}$ software and refined using SAINTPlus ${ }^{45}$ on all observed reflections. Data reduction and correction for Lorentz-polarization and decay were performed using the SAINTPlus software. Absorption corrections were applied using SADABS. ${ }^{46}$ The structure was solved by direct methods and refined by least-squares method on $\mathrm{F}^{2}$ using the SHELXTL program package. ${ }^{47}$ The space groups were determined on the basis of systematic absences and intensity statistics. All non-hydrogen atoms were refined anisotropically. Hydrogen atoms were placed at idealized positions and refined with fixed isotropic displacement parameters. The pinched proton for isomers $\mathbf{B}$ and $\mathbf{C}$ was placed between two $\mathrm{N}$ atoms using restraints to have equal $\mathrm{N}-\mathrm{H}$ distance and refined. No decomposition was observed during data collection. Further details are provided in the Supporting Information.

\section{ASSOCIATED CONTENT}

\section{Supporting Information}

Crystallographic data for complex 2, B, and C in CIF format, and graphs for electrocatalytic response for hydrogen oxidation of $\left[\mathrm{Ni}\left(\mathrm{P}^{\mathrm{Cy}}{ }_{2} \mathrm{~N}^{t-\mathrm{Bu}}{ }_{2}\right)_{2}\right]^{2+}$ under different conditions. This material is available free of charge via the Internet at http://pubs.acs.org.

\section{AUTHOR INFORMATION}

\section{Corresponding Author}

j.yang@uci.edu; morris.bullock@pnnl.gov

\section{Present Address}

${ }^{\S}$ Department of Chemistry, University of California Irvine, Irvine, California 92697, United States.

\section{Notes}

The authors declare no competing financial interest.

\section{ACKNOWLEDGMENTS}

We thank Dr. Michael Stewart, Dr. Monte Helm, and Dr. Aaron Appel for helpful discussions. This research was supported as part of the Center for Molecular Electrocatalysis, an Energy Frontier Research Center funded by the U.S. 
Department of Energy, Office of Science, Basic Energy Sciences. Pacific Northwest National Laboratory is operated by Battelle for the U.S. Department of Energy.

\section{REFERENCES}

(1) Lewis, N. S.; Nocera, D. G. Proc. Natl. Acad. Sci. U. S. A. 2006, 103, 15729-15735.

(2) Friedman, D. M., T.; Olson, S. The Role of the Chemical Sciences in Finding Alternatives to Critical Resources: A Workshop Summary; The National Academies Press: Washington, D.C., 2012.

(3) Rakowski DuBois, M.; DuBois, D. L. In Catalysis Without Precious Metals; Bullock, R. M., Ed.; Wiley: Weinheim, 2010; Chapter 7.

(4) Wang, M.; Chen, L.; Sun, L. Energy Environ. Sci. 2012, 5, 67636778 .

(5) Thoi, V. S.; Sun, Y.; Long, J. R.; Chang, C. J. Chem. Soc. Rev. 2013, 42, 2388-2400.

(6) Wilson, A. D.; Newell, R. H.; McNevin, M. J.; Muckerman, J. T.; Rakowski DuBois, M.; DuBois, D. L. J. Am. Chem. Soc. 2006, 128, 358-366.

(7) Wilson, A. D.; Shoemaker, A.; Miedaner, A.; Muckerman, J. T.; DuBois, D. L.; Rakwoski DuBois, M. Proc. Natl. Acad. Sci. U. S. A. 2007, 104, 6951-6956.

(8) Fraze, K.; Wilson, A. D.; Appel, A. M.; Rakowski DuBois, M.; DuBois, D. L. Organometallics 2007, 26, 3918-3924.

(9) Appel, A. M.; Pool, D. H.; O’Hagan, M.; Shaw, W. J.; Yang, J. Y.; Rakowski DuBois, M.; DuBois, D. L.; Bullock, R. M. ACS Catal. 2011, 1, 777-785.

(10) Helm, M. L.; Stewart, M. P.; Bullock, R. M.; Rakowski DuBois, M.; DuBois, D. L. Science 2011, 333, 863-866.

(11) Jain, A.; Lense, S.; Linehan, J. C.; Raugei, S.; Cho, H.; DuBois, D. L.; Shaw, W. J. Inorg. Chem. 2011, 50, 4073-4085.

(12) Kilgore, U. J.; Roberts, J. A. S.; Pool, D. H.; Appel, A. M.; Stewart, M. P.; Rakowski DuBois, M.; Dougherty, W. G.; Kassel, W. S.; Bullock, R. M.; DuBois, D. L. J. Am. Chem. Soc. 2011, 133, 5861-5872.

(13) Pool, D. H.; DuBois, D. L. J. Organomet. Chem. 2009, 694, 2858-2865.

(14) Jacques, P.-A.; Artero, V.; Pecaut, J.; Fontecave, M. Proc. Natl. Acad. Sci. U. S. A. 2009, 106, 20627-20632.

(15) Kilgore, U. J.; Stewart, M. P.; Helm, M. L.; Dougherty, W. G.; Kassel, W. S.; Rakowski DuBois, M.; DuBois, D. L.; Bullock, R. M. Inorg. Chem. 2011, 50, 10908-10918.

(16) Wilson, A. D.; Fraze, K.; Twamley, B.; Miller, S. M.; DuBois, D. L.; Rakowski DuBois, M. J. Am. Chem. Soc. 2008, 130, 1061-1068.

(17) Jacobsen, G. M.; Yang, J. Y.; Twamley, B.; Wilson, A. D.; Bullock, R. M.; Rakowski DuBois, M.; DuBois, D. L. Energy Environ. Sci. 2008, 1, 167-174.

(18) Wiedner, E. S.; Yang, J. Y.; Dougherty, W. G.; Kassel, W. S.; Bullock, R. M.; Rakowski DuBois, M.; DuBois, D. L. Organometallics 2010, 29, 5390-5401.

(19) Berben, L. A.; Peters, J. C. Chem. Commun. 2010, 46, 398-400.

(20) Szymczak, N. K.; Berben, L. A.; Peters, J. C. Chem. Commun. 2009, 6729-6731.

(21) Artero, V.; Chavarot-Kerlidou, M.; Fontecave, M. Angew. Chem., Int. Ed. Engl. 2011, 50, 7238-7266.

(22) McCrory, C. C. L.; Uyeda, C.; Peters, J. C. J. Am. Chem. Soc. 2012, 134, 3164-3170.

(23) Stubbert, B. D.; Peters, J. C.; Gray, H. B. J. Am. Chem. Soc. 2011, 133, 18070-18073.

(24) Dempsey, J. L.; Winkler, J. R.; Gray, H. B. J. Chem. Soc., Dalton Trans. 2011, 40, 10633-10636.

(25) Lee, C. H.; Dogutan, D. K.; Nocera, D. G. J. Am. Chem. Soc. 2011, 133, 8775-8777.

(26) Chen, J.; Vannucci, A. K.; Mebi, C. A.; Okumura, N.; Borowski, S. C.; Swenson, M.; Lockett, L. T.; Evans, D. H.; Glass, R. S.; Lichtenberger, D. L. Organometallics 2010, 29, 5330-5340.

(27) Tard, C.; Pickett, C. J. Chem. Rev. 2009, 109, 2245-2274.
(28) Chong, D. S.; Georgakaki, I. P.; Mejia-Rodriguez, R.; SamabriaChinchilla, J.; Soriaga, M. P.; Darensbourg, M. Y. J. Chem. Soc., Dalton Trans. 2003, 4158-4163.

(29) Ott, S.; Kritikos, M.; Akermark, B.; Sun, L. C.; Lomoth, R. Angew. Chem., Int. Ed. Engl. 2004, 43, 1006-1009.

(30) Mejia-Rodriguez, R.; Chong, D. S.; Reibenspies, J. H.; Soriaga, M. P.; Darensbourg, M. Y. J. Am. Chem. Soc. 2004, 126, 12004-12014.

(31) Rose, M. J.; Gray, H. B.; Winkler, J. R. J. Am. Chem. Soc. 2012, $134,8310-8313$.

(32) Gloaguen, F.; Lawrence, J. D.; Rauchfuss, T. B.; Benard, M.; Rohmer, M. M. Inorg. Chem. 2002, 41, 6573-6582.

(33) Barton, B. E.; Olsen, M. T.; Rauchfuss, T. B. J. Am. Chem. Soc. 2008, 130, 16834-16835.

(34) Karunadasa, H. I.; Chang, C. J.; Long, J. R. Nature 2010, 464, 1329-1333.

(35) Karunadasa, H. I.; Montalvo, E.; Sun, Y. J.; Majda, M.; Long, J. R.; Chang, C. J. Science 2012, 335, 698-702.

(36) Simándi, L. I.; Szeverényi, Z.; Budó-Záhonyi, É. Inorg. Nucl. Chem. Lett. 1975, 11, 773-777.

(37) Collman, J. P.; Slaughter, L. M.; Eberspacher, T. A.; Strassner, T.; Brauman, J. I. Inorg. Chem. 2001, 40, 6272-6280.

(38) Hu, X.; Brunschwig, B. S.; Peters, J. C. J. Am. Chem. Soc. 2007, 129, 8988-8998.

(39) Olsen, M. T.; Barton, B. E.; Rauchfuss, T. B. Inorg. Chem. 2009, 48, 7507-7509.

(40) Heiden, Z. M.; Zampella, G.; De Gioia, L.; Rauchfuss, T. B. Angew. Chem., Int. Ed. Engl. 2008, 47, 9756-9759.

(41) Gloaguen, F.; Rauchfuss, T. B. Chem. Soc. Rev. 2009, 38, 100108.

(42) Ringenberg, M. R.; Nilges, M. J.; Rauchfuss, T. B.; Wilson, S. R. Organometallics 2010, 29, 1956-1965.

(43) Ringenberg, M. R.; Kokatam, S. L.; Heiden, Z. M.; Rauchfuss, T. B. J. Am. Chem. Soc. 2008, 130, 788-789.

(44) Ogo, S. Chem. Commun. 2009, 3317-3325.

(45) Kuwata, S.; Ikariya, T. J. Chem. Soc., Dalton Trans. 2010, 39, 2984-2992.

(46) Curtis, C. J.; Miedaner, A.; Ciancanelli, R.; Ellis, W. W.; Noll, B. C.; DuBois, M. R.; DuBois, D. L. Inorg. Chem. 2003, 42, 216-227.

(47) Collman, J. P.; Wagenknecht, P. S.; Hutchison, J. E.; Lewis, N. S.; Lopez, M. A.; Guilard, R.; Lher, M.; Bothnerby, A. A.; Mishra, P. K. J. Am. Chem. Soc. 1992, 114, 5654-5664.

(48) Yang, J. Y.; Bullock, R. M.; Shaw, W. J.; Twamley, B.; Fraze, K.; Rakowski DuBois, M.; DuBois, D. L. J. Am. Chem. Soc. 2009, 131, 5935-5945.

(49) Camara, J. M.; Rauchfuss, T. B. J. Am. Chem. Soc. 2011, 133, 8098-8101.

(50) Yang, J. Y.; Chen, S. T.; Dougherty, W. G.; Kassel, W. S.; Bullock, R. M.; DuBois, D. L.; Raugei, S.; Rousseau, R.; Dupuis, M.; Rakowski DuBois, M. Chem. Commun. 2010, 46, 8618-8620.

(51) Camara, J. M.; Rauchfuss, T. B. Nat. Chem. 2012, 4, 26-30.

(52) Liu, T.; DuBois, D. L.; Bullock, R. M. Nat. Chem. 2013, 5, 228233.

(53) Fontecilla-Camps, J. C.; Volbeda, A.; Cavazza, C.; Nicolet, Y. Chem. Rev. 2007, 107, 5411-5411.

(54) Cracknell, J. A.; Vincent, K. A.; Armstrong, F. A. Chem. Rev. 2008, 108, 2439-2461.

(55) DuBois, D. L.; Bullock, R. M. Eur. J. Inorg. Chem. 2011, 10171027.

(56) Rakowski DuBois, M.; DuBois, D. L. C. R. Chim. 2008, 11, 805817.

(57) Rakowski DuBois, M.; DuBois, D. L. Chem. Soc. Rev. 2009, 38, $62-72$.

(58) Yang, J. Y.; Bullock, M.; Rakowski DuBois, M.; DuBois, D. L. MRS Bull. 2011, 36, 39-47.

(59) Dempsey, J. L.; Winkler, J. R.; Gray, H. B. J. Am. Chem. Soc. 2010, 132, 16774-16776.

(60) Yang, J. Y.; Bullock, R. M.; Dougherty, W. G.; Kassel, W. S.; Twamley, B.; DuBois, D. L.; Rakowski DuBois, M. J. Chem. Soc., Dalton Trans. 2010, 39, 3001-3010. 
(61) Evans, D. F. J. Chem. Soc. 1959, 2003-2005.

(62) Schubert, E. M. J. Chem. Educ. 1992, 69, 62.

(63) Grant, D. H. J. Chem. Educ. 1995, 72, 39-40.

(64) O’Hagan, M.; Shaw, W. J.; Raugei, S.; Chen, S.; Yang, J. Y.; Kilgore, U. J.; DuBois, D. L.; Bullock, R. M. J. Am. Chem. Soc. 2011, 133, 14301-14312.

(65) He, T.; Tsvetkov, N. P.; Andino, J. G.; Gao, X. F.; Fullmer, B. C.; Caulton, K. G. J. Am. Chem. Soc. 2010, 132, 910-911.

(66) Tsay, C.; Peters, J. C. Chem. Sci 2012, 3, 1313-1318.

(67) Kaljurand, I.; Kütt, A.; Sooväli, L.; Rodima, T.; Mäemets, V.;

Leito, I.; Koppel, I. A. J. Org. Chem. 2005, 70, 1019-1028.

(68) Berning, D. E.; Noll, B. C.; DuBois, D. L. J. Am. Chem. Soc. 1999, 121, 11432-11447.

(69) Wayner, D. D. M.; Parker, V. D. Acc. Chem. Res. 1993, 26, 287294.

(70) Miedaner, A.; Haltiwanger, R. C.; DuBois, D. L. Inorg. Chem. 1991, 30, 417-427.

(71) Curtis, C. J.; Miedaner, A.; Raebiger, J. W.; DuBois, D. L. Organometallics 2004, 23, 511-516.

(72) Curtis, C. J.; Miedaner, A.; Ellis, W. W.; DuBois, D. L. J. Am. Chem. Soc. 2002, 124, 1918-1925.

(73) Wiedner, E. S.; Yang, J. Y.; Chen, S. T.; Raugei, S.; Dougherty, W. G.; Kassel, W. S.; Helm, M. L.; Bullock, R. M.; Rakowski DuBois, M.; DuBois, D. L. Organometallics 2012, 31, 144-156.

(74) Wiese, S.; Kilgore, U. J.; DuBois, D. L.; Bullock, R. M. ACS Catal. 2012, 2, 720-727.

(75) Roberts, J. A. S.; Bullock, R. M. Inorg. Chem. 2013, 52, 38233835.

(76) Nicholson, R. S.; Shain, I. Anal. Chem. 1964, 36, 706-723.

(77) Savéant, J. M.; Vianello, E. Electrochim. Acta 1967, 12, 629-646.

(78) Savéant, J. M.; Vianello, E. Electrochim. Acta 1965, 10, 905-920.

(79) Wilson, A. D.; Fraze, K.; Twamley, B.; Miller, S. M.; DuBois, D. L.; Rakowski DuBois, M. J. Am. Chem. Soc. 2007, 130, 1061-1068.

(80) O’Hagan, M. J.; Ho, M.-H.; Yang, J. Y.; Appel, A. M.; Rakowski DuBois, M.; Raugei, S.; Shaw, W. J.; DuBois, D. L.; Bullock, R. M. J. Am. Chem. Soc. 2012, 134, 19409-19424.

(81) Brammer, L. J. Chem. Soc., Dalton Trans. 2003, 3145-3157.

(82) Brammer, L.; Mareque Rivas, J. C.; Spilling, C. D. J. Organomet. Chem. 2000, 609, 36-43.

(83) Cecconi, F.; Ghilardi, C. A.; Innocenti, P.; Mealli, C.; Midollini, S.; Orlandini, A. Inorg. Chem. 1984, 23, 922-929.

(84) Epstein, L. M.; Shubina, E. S. Coord. Chem. Rev. 2002, 231, $165-181$.

(85) Shubina, E. S.; Belkova, N. V.; Epstein, L. M. J. Organomet. Chem. 1997, 536-537, 17-29.

(86) Gagné, R. R.; Koval, C. A.; Lisensky, G. C. Inorg. Chem. 1980, $19,2854-2855$.

(87) Gritzner, G.; Kuta, J. Pure Appl. Chem. 1984, 56, 461-466.

(88) Appel, A. M.; DuBois, D. L.; DuBois, M. R. J. Am. Chem. Soc. 2005, 127, 12717-12726.

(89) Rodima, T.; Kaljurand, I.; Pihl, A.; Maemets, V.; Leito, I.; Koppel, I. A. J. Org. Chem. 2002, 67, 1873-1881. 